Article

\title{
Human-Centred Indicators (HCI) to Regenerate Vulnerable Cultural Heritage and Landscape towards a Circular City: From the Bronx (NY) to Ercolano (IT)
}

\author{
Martina Bosone ${ }^{1, *(\mathbb{D})}$ and Francesca Ciampa ${ }^{2, *(\mathbb{D})}$ \\ 1 CNR-IRISS, National Research Center on Innovation and Services for Development, 80134 Naples, Italy \\ 2 DiARC, Department of Architecture, University of Naples Federico II, 80100 Naples, Italy \\ * Correspondence: m.bosone@iriss.cnr.it (M.B.); francesca.ciampa@unina.it (F.C.); Tel.: +39-368-767-5982 (M.B.)
}

Citation: Bosone, M.; Ciampa, F. Human-Centred Indicators (HCI) to Regenerate Vulnerable Cultural Heritage and Landscape towards a Circular City: From the Bronx (NY) to Ercolano (IT). Sustainability 2021, 13, 5505. https://doi.org/10.3390/ su13105505

Academic Editor: Asterios Bakolas

Received: 9 February 2021

Accepted: 11 May 2021

Published: 14 May 2021

Publisher's Note: MDPI stays neutral with regard to jurisdictional claims in published maps and institutional affiliations.

Copyright: (C) 2021 by the authors. Licensee MDPI, Basel, Switzerland. This article is an open access article distributed under the terms and conditions of the Creative Commons Attribution (CC BY) license (https:// creativecommons.org/licenses/by/ $4.0 /)$.

\begin{abstract}
Many cities globally are incorporating the circular economy model into their development strategies to start transitioning as "circular cities" towards the implementation of human-centred development. In many of them, one of the major challenges is represented by the large presence of cultural heritage being in a state of degradation, abandonment and underutilization, which determines waste conditions not only at physical/spatial level but also at economic level (the presence of subsistence economies) and at a social and cultural level (marginalization phenomena and high rates of unemployment). The perspective of circular economy allows rethinking these waste conditions as an opportunity to reactivate virtuous circuits capable of promoting sustainable development focused on human needs. In this perspective, the paper aims to demonstrate both the importance of participatory approaches in guiding circular and human-centred regeneration processes and of identifying evaluation tools capable of integrating the human and ecological dimension with the economic one. With this aim, a circular methodology is proposed and experimented with in Ercolano (Italy) and in the Bronx (New York), in which the adoption of a participatory approach was central in all phases of regeneration processes, from the identification and analysis of vulnerabilities and waste conditions to the definition of a strategy capable of transforming these limitations into opportunities. A first result is the elaboration of a framework of "Human-Centred Indicators" to monitor and support the adoption of the circular economy strategy toward implementing the "human-centred city".
\end{abstract}

Keywords: circular city; community-led strategies; cultural heritage; evaluation framework; humancentred approach; participatory approach

\section{Introduction}

Each crisis can be an opportunity to reflect both on its related causes and on how to increase the resilience of cultural heritage and landscape through regeneration strategies. From this point of view, the critical issues arising from the COVID-19 pandemic crisis, have generated political, economic, and social challenges that offer the opportunity to orient future strategies towards a more sustainable development especially for vulnerable cultural heritage and landscape [1,2]. The pandemic emergency has highlighted the need to elaborate new tools to support a just, equitable and fair transition towards "HumanCentred and Circular City" [3-8].

In this sense, the current pandemic has further shown the fragility of development strategies based on the exploitation of natural resources, on the maximization of the economic profit of a few and on deprivation of rights in decision making [3]. This is why it is important that future regeneration strategies will adopt approaches able to protect communities and businesses from climate-related shocks. In order to transform vulnerable cultural heritage and landscape consistently with the approaches described, urban regeneration practices must act in the perspective of circular models. These have the ability to grasp environmental, economic, and social criticalities as an opportunity to 
regenerate vulnerable cultural heritage and landscape towards circular city transitions. This circular perspective inseparably links urban regeneration practices to people's health and wellbeing, stressed by the pandemic condition described above.

The proposal analyzes how the participation of different actors in the regeneration process represents a fundamental condition to achieve sustainable development goals [9] by promoting an inclusive approach able to integrate different actors in the whole planning process [10-15]. The operational approach proposed in the paper is based on the collaboration and co-production of stakeholders as enablers of policies and actions. It highlights the role of citizens as "city makers" and as "innovation actors" in participatory governance [16] contributing to the definition of policies in a "city for all" [3]. In this scenario, the research integrates human-centred and circular economy approaches for the implementation of circular city models. This proposes a two-fold research innovation: the first is a process innovation, adopting a participatory approach deducted from the comparison between international guidelines and based on a multi-stakeholders involvement in decision making; the second is a product innovation related to the identification of "Human-Centred Indicators" both to evaluate and monitor regeneration practices and to support and orient the elaboration of future strategies for implementing the circular city model.

The aim is to elaborate a clear and replicable methodology both to define shared, inclusive and sustainable development strategies and to assure a fair and equitable transition towards a human-centred and circular city model. Putting people and culture at the centre of the circular human regeneration means to consider human needs as the main objective. The integration of this perspective with the circular economy model allows to interpret human needs co-existing and co-evolving with economic, ecological, and social values, thus allowing the implementation of a human-centred strategy [17-19].

In this perspective, cities represent the spatial dimension in which the humanization project can be implemented at a human scale and the regeneration of cultural heritage and landscape assumes the role of entry point for implementing the circular city model. Culture represents the filter, which over time, people have shaped the physical and environmental context in which they live [20]. Furthermore, the cultural heritage and landscape could be considered as the result of the interaction between people and their living context, embedding a set of tangible and intangible values (environmental, social/cultural, economic, symbolic, aesthetic, historical, spiritual, etc.) which are the testimony of this symbiotic relation. In turn, landscape shapes the people's behaviors [20] as the quality of the landscape, which includes the quality of places, of infrastructure, of human and social capital and the institutions therein. It influences the whole productivity of an urban system affecting the quality of people's life who live there. This circular, symbiotic and reciprocal process between man and landscape, is recognized as an "intrinsic value" [18,21,22] which represents a factor of permanence in the transformative dynamics of cultural heritage and landscape, assuring an evolutionary continuity [23] based on the co-evolution and regeneration of material and immaterial values. Indeed, the "intrinsic value" represents the fundamental value on which other values are founded on and which have oriented the shaping actions in the built and natural environments, influencing the other dimensions of the values as well.

As man began to conceive of his development in a selfish manner aimed at maximizing economic profit, the co-evolutionary relationship with both landscape and other living beings was increasingly weakened. This cultural change has been reflected at the spatial level: in fact, space previously represented the dimension in which to cultivate the sense and meaning of "being together" in a community $[19,24,25]$. Over time it has progressively assumed an instrumental value with respect to the maximization of individual interests, determining the current vulnerabilities and waste conditions.

Regenerating vulnerable and discarded cultural heritage and landscape [24,26-28] means reconnecting human beings to nature [17], and re-building the symbiotic relationships among them into a systemic perspective. In this context, the human capital, the social cohesion, the solidarity, the common identity, the participation of the local stakeholders 
and decision makers, the feeling of confidence in the future of the city and in interpersonal relations and relations between citizens and institutions $[19,24]$ emphasize the role of culture as a driver for change and development in the city [29].

Integrating the human-centred into a circular perspective allows to consider the landscape regeneration as a "multiplier of values" [17] able to regenerate the vitality of vulnerable and discarded cultural heritage and landscape, transforming them into a "living system" [17,30,31]. This vision highlights the importance of relational dimensions in which all values co-evolve together through virtuous and circular processes. The latter, putting the human beings at the centre, can satisfy their needs, guaranteeing the preservation and the development of the other values.

Assuming human needs as the centre point of research approach, highlights the importance to experiment with inclusive strategies for triggering circular processes to build a circular city as a "city of man on a human scale" [32-35]. In this perspective, the circular and human-centred city is able to regenerate all forms of the existing cultural heritage capital (natural, manmade, cultural, social, economic and human) [8,20] as key factors for achieving the sustainable development goals.

The paper adopts the human-centred approach as a precondition to implement circular regeneration strategy, improving collective memory, and community bonds. This represents the first step to rebuild the attractiveness of places and to create new flourish opportunities for the communities by enhancing the potential of local social and human capital. The research looks at the human-centred approach to test participatory tools for implementing the circular city model as a "regenerative city" [36,37] at a multidimensional level, considering at the same time cultural, economic, ecologic and social values.

Starting from the above considerations, the paper proposes the comparison of two experiments conducted in Ercolano (Italy) and Bronx (NY), chosen as contexts in which the coexistence of vulnerabilities and conditions of discard occurs at the physical/spatial, economic, social, and cultural levels. These case studies let the research test specific participation tools (interviews and questionnaires) according to a bottom-up approach, to assess both the expressed needs and the expectations about potential positive impacts of the proposed strategies.

The document is organized into four sections. Section 2 explores from a theoretical point of view the human-centred approach in the American school and in the European school, focusing on their origins, the state of the art and the tools. Section 2 has been structured in this way to represent the state of art of circularity, social and economic regeneration in vulnerable settlement systems. This literature review links the themes of co-design and the participatory approach to the collaborative regeneration of the built environment in order to present the next section. Section 3 introduces the methodological approach that, starting from the Section 2 consideration of need to define a more humancentred and inclusive development strategy, proposes a new analyzing strategies and tools. In order to test what was announced in Section 3, Section 4 presents the two case studies of Ercolano and the Bronx. In this scenario Section 5 analyses the two case studies focusing on the implementation of participatory methods and tools identifying general issues (Section 5.1). It lets us respond with international criteria of sustainable development, climate strategies, circular economy model and human-centred approach, in order to define "Human-Centred Evaluation Matrix" (HCEM) and "Human-Centred Indicators (HCI)" towards a human-centred and circular city (Section 5.2).

\section{The Human-Centred Approach: A Literature Review}

In the theoretical framework, the human-centred approach shifts from the individual to the community dimension, determining connections between people, design action and social innovation. This relational model creates processes of social cohesion and cultural heritage and landscape regeneration. Adopting the human-centred approach in participatory practices means to give particular attention to the value of trust [38] and cooperation as an enabler to enhance social cohesion and to stimulate circular relationships, synergies 
and symbioses. It lays the foundations for a design-oriented regeneration of settlement systems according to a double vision: design-as-practice and design-as-meaning [39]. The design-as-practice is based on participation and practical involvement in reference to sociological theory applied to collaborations $[40,41]$. On the other hand, the design-as-meaning is based on the theory of design linked to the search for shared values for the construction of a common horizon. The two approaches work in a complementary way to achieve a regeneration of settlement systems whose transformations affect both the physicality of the places and the meaning they assume as a result of shared changes. This determines the development of a network of relationships capable of creating concrete and symbolic actions in the social construction of circular and sustainable reality [21]. The comparison of an American and European human-centred vision lets the research build an exhaustive framework from origin to future directions. In literature it is interesting because it matches the American vision as a pioneer in the sector of participation and the European one as a more advanced future vision.

The American vision dates back to the second half of the 20th century linked human needs and citizen participation with a human-centred approach [42]. This vision has matured over time to the point of becoming a promoter of inclusive tools aimed at involving citizens for the construction of shared settlement transformations [43]. The services required for the settlement transition are a response to the transformative needs of the community [44] In participatory planning, stakeholders (putative, potential or future) are invited to collaborate with decision makers in the innovation process both in the analysis, planning, design and management phases, contributing to the evaluation of the proposed solutions [45]. Participatory planning evolves as part of the value co-creation process, based on the stakeholders' needs, which play a central role in settlement transformations [46-50]. According to the American future perspectives based on the vision of Humanhattan 2050, the human-centred approach and co-design produce a collective process capable of exerting a direct impact on social sustainability. It is able to cultivate a sense of belonging and promote participation and integration between places and people, acting on the concept of settlement systems identity without altering it [51,52].

The European vision linked to human-centred approaches makes cities and human settlements inclusive, safe, resilient, and sustainable $[9,53,54]$ to ensure that anticipated regenerative transitions are socially fair. The latest documents from the European Commission [3,4] describe how the human-centred city is achieved through research and innovation actions in six fields: "people", "place", "prosperity", "resilience", "governance", and "measuring innovative cities". The European vision promises the ability to accelerate the transition to inclusive, resilient, safe, climate-proof and resource-efficient ecosystems in the opportunity of involving citizens. The European vision thus opens up a reflection on how to face global urban challenges by assuming a holistic, participatory and inclusive perspective.

These visions, American and European ones, share the need for the transition to a new human-centred paradigm and therefore imply a change in the culture of landscape transformations, which represents the product of human beings as it influences the uses of spaces by establishing relationships between man and their living environment. The regeneration practices that move from the aforementioned directives of the human-centred visions aim to develop the creative capacity of the human being. The latter was involved in the empowerment of local communities in terms of active citizenship, proactive participation and capacity for self-organization [17]. These visions push the community to evolve from "collective thinking" to "collective action" by assuming social equity as a common good with a shared value. In the human-centred approach, social equity aims to support the different actors of the process in a differentiated way. It bridges the latent disparities in order to guarantee an equitable final distribution of possibilities and the satisfaction of individual needs in order to respect collective ones [4]. In this sense, justice and social equity are seen as essential assets for social, economic, and personal development and as a service for the community. When society creates the necessary conditions for the individual experience of 
global well-being, it will be possible to live on sustainable processes of interdependence for the achievement of common goals [3]. This relationship of mutual connection between cultural heritage and landscape chooses participatory tools of dialogue and inclusion to create a collective identity aimed at increasing in individuals the sense of responsibility to safeguard their cultural heritage. It makes the best use of common resources and to avoid waste [55]. In this perspective, the regeneration of vulnerable cultural heritage and landscape through a human-centred approach becomes a "productive activity" [8]. It multiplies values while preserving existing ones and producing "new" ones in multiple dimensions. The implementation of a human-centred approach in circular regeneration strategies requires first of all the identification of the "intrinsic value" [22] of the cultural heritage and landscape, interpreted as a spatial expression of the relationship between man and landscape. This perspective regenerates the "complex value" of the landscape [21,22], considering it as a "complex system" $[8,56]$. In this scenario, the circular economy, understood as the economy of the co-evolution of man [57] and relationships, allows to adopt a systemic vision, attentive to interdependencies. Human-centred exploits the circular principle of closing cycles, spoken for the first time by Barry Commoner in "The Closing Circle" in 1971 [58], to identify an approach that reduces/eliminates waste and underuse, through activation of closed cycles. Associating circularity with the human-centred vision allows the research to activate processes of collaboration, cooperation, and symbiosis between different actors (economic, public, social). The most interesting aspect of this association is that the aforementioned regeneration processes involve different actors. This generates a density of interpersonal relationships which affect mutual exchanges, improving the outcome of transformations. Adopting a circular approach within the human-centred vision means integrating the multidimensional impacts of social transformations by grasping the complexity of the values involved in the regeneration processes [31].

Adopting the human-centred vision, urban regeneration strategies require a paradigm shift in which all economic values coexist and co-evolve with ecological and social values, thus allowing the implementation of a strategy that is human-centred [30]. The humancentred development strategy assumes human needs as a relational perspective of "human flowering" [59]. This means that the new human-centred regeneration strategies must take into account the physical transformation impacts of space, the social, environmental and economic level. In this scenario, the centrality of the human being goes beyond the anthropocentric vision to highlight the relationships, in space and time, between human beings and nature [17]. This reasoning brings together different processes that increase performance, being generators of creative energy, new opportunities, and original complementarities. It gives life to cooperative relationships in which each party receives and in turn offers in a circuit of reciprocity, that is, of benefits for everyone.

\section{Methodology}

The proposed methodology presents a double level of innovation. The first is a process of innovation where local stakeholders are considered in all phases of the experimentation and their needs are considered simultaneously as the input and output of the circular methodology. In fact, the confrontation between institutions, expert knowledge and community allows to identify and analyze expressed and potential needs to be met and for this reason they represent an input for the identification and analysis of vulnerabilities and waste conditions to be answered in the elaboration of the regeneration strategy. Similarly, these needs guide the choice of strategy to be adopted and condition the definition of outputs in terms of actions to be undertaken and tools to be used for monitoring and evaluation of their satisfaction. 
The second is a product innovation in that the results of the dialogue between the various local stakeholders are interpreted by expert knowledge as a starting point for relating local needs to international directives on circular economy [60], current challenges of regeneration strategies [61], ecological transition [53], sustainable development [9] and a human-centred approach $[3,4]$ through the definition of general criteria, from which to deduce an assessment framework based on the identification of indicators to support decision-making and to monitor and assess the multidimensional impacts of circular strategies towards the implementation of a human-centred city.

The research dwells in particular on the heritage and cultural landscape in a state of degradation, abandonment and disuse present in the two case studies, Ercolano (Italy) and the Bronx (New York), chosen as contexts in which the coexistence of vulnerabilities and conditions of discard occurs at the physical/spatial, economic, social and cultural levels. The perspective adopted is that of the UNESCO Recommendations [56] which, considering the landscape as a superposition of multiple layers, guides its classification based on the decomposition into sub-systems.

The methodology is based on the following five steps:

Phase 1. The discretization of the examined complex urban system in sub-systems, distinguished in environmental subsystem (SEn), social sub-system (SS), economic subsystem (SE) and cultural sub-system (SC). For the latter, a clarification is needed: the perspective adopted in this research assumes culture as a crosscutting dimension, which has influenced, and today orients, the social, environmental and economic dynamics. However, in both cases the identification of a cultural sub-system implies that the analysis of physical assets (buildings or spaces) has a cultural value and an evident expression of a determined culture in a specific time. The discretization is useful to identify waste/vulnerability factors in each sub-system and, thus, to identify the key issues to be reinterpreted as potential resources for the development of human-centred regeneration strategies.

Phase 2. Identification of decision makers and stakeholders. Downstream of the previous discretization phase of the case to be examined, it is possible to identify emerging and specific issues for each of the sub-systems analyzed. The identification of each issue allows the identification of related decision-makers, considering their responsibility in responding and influencing the issue of related sub-system [62].

Phase 3. Implementation of an integrated and participatory approach through engagement tools. Considering the above mentioned complexity, which characterizes the definition of a landscape, it was necessary to integrate vulnerabilities and waste conditions identified in phase 1 from an experts' point of view, also with subjective weakness and threats derived from how people perceive the place where they live. In this perspective, the integration of Multi-Stakeholder Engagement Processes (MSEPs) [63] and Multi-Stakeholder Decision Analysis (M-SDA) [64] was useful both to involve local stakeholders and decision makers in analyzing the quality of their living environment (and consequently of their life), engaging them also in the development of appropriate development strategies to manage their physical, economic and social environments.

Phase 4. Identification of main critical issues interpreting and reorganizing expressed needs and perception derived from the engagement phase (phase 3). In this phase, the main critical issues of each case study were compared in two matrix for the identification of "Negative Common Contact Points (NCCP)" and, starting from these, of "Positive Common Contact Points (PCCP)".

Phase 5. Elaboration of "Human-Centred Indicators Matrix" (HCI) to operationalize the "circular economy" strategy toward implementing the "human-centered city". Starting from a literature review about the use of indicators related to circular economy, regeneration strategies, ecological transition, sustainable development, and a human-centred approach, we propose a set of "Human-Centred Indicators".

All phases of the proposed methodology are interlinked and configure a circular process, in which stakeholders and decision makers are the core of a social innovation process and the real driver able to orient the elaboration of regeneration strategies, from 
the knowledge phase, through the planning and design, towards the implementation and monitoring.

The circular methodology is clarified in Figure 1.

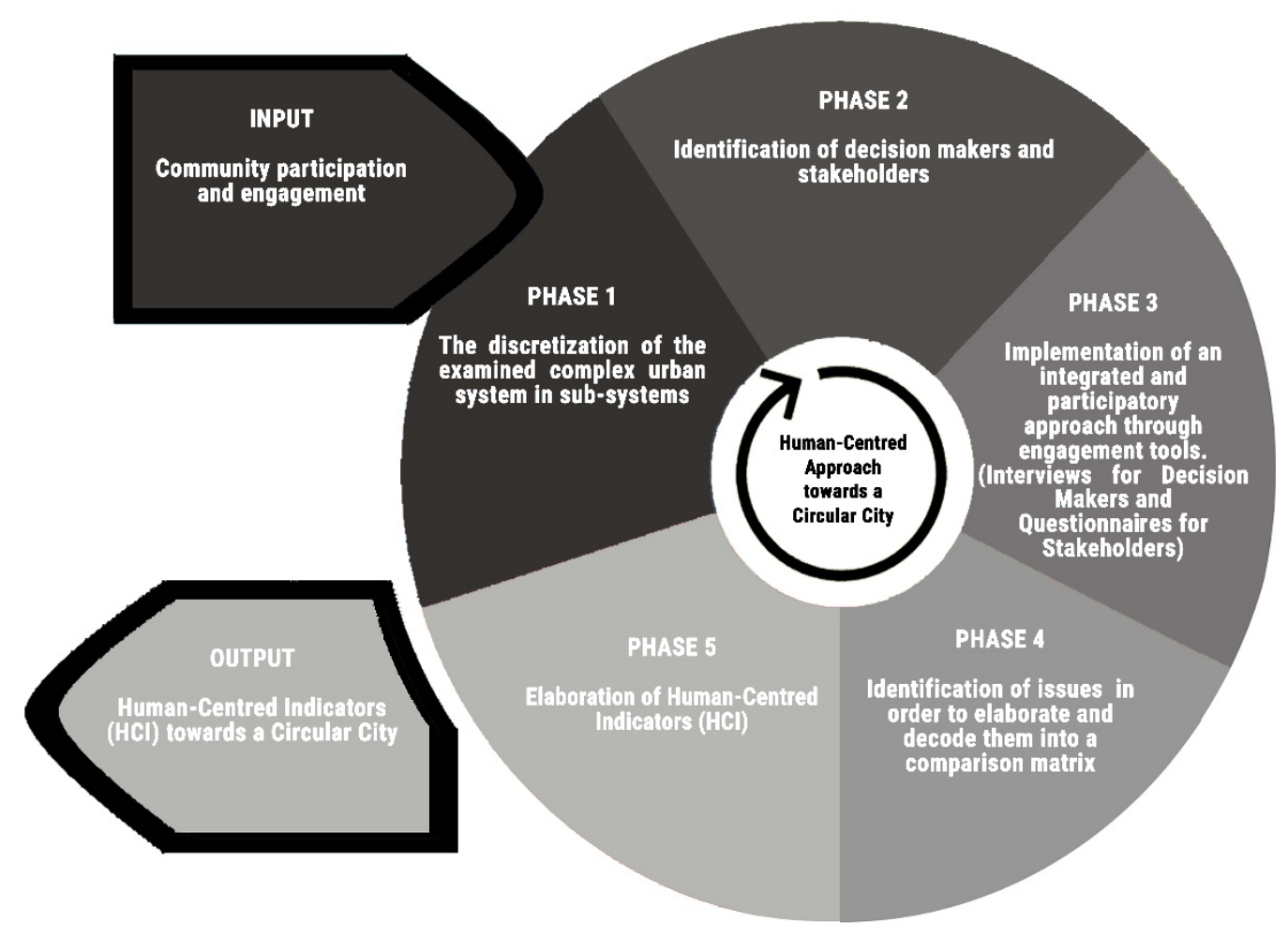

Figure 1. Methodological scheme. Source: elaboration of authors.

\section{The Participatory Approach for Human-Centred and Circular Regeneration: The Cases of the Bronx (New York) and Ercolano (Italy)}

The choices of the two urban cases fall on the Bronx and on Ercolano as case studies, in which the human-centred vision is experimented through the implementation of participation strategies in urban contexts. These case studies are characterized by duality: on one hand there are great cultural and environmental resources, with a high unexpressed potential, and on the other hand there is the presence of cultural, social, environmental and economic waste that make them a highly vulnerable and fragmented context. The experimentations here conducted the experimentation that will allow to define a methodology for human-centred and circular regeneration that is transferable and replicable in other territorial realities affected by the same fragile conditions.

The case study of the Bronx, neighborhoods of New York, was chosen to be a practice in which urban regeneration takes place through the active involvement of communities. The stakeholders try to redeem themselves from the social and economic marginalization of a place exploiting the great local transformative potential. The Bronx represents a border area or rather the border between a heavily degraded site and the unbridled wealth of Manhattan. Since 2012, after Hurricane Sandy, the Bronx has taken the opportunity to protect itself from catastrophic climatic events to intervene on the processes of urban regeneration and gentrification that afflict the area. The cultural heritage and landscape of the Bronx, with specific reference to the South Bronx, has historical importance accompanied by the high rates of crime, economic deficit and social segregation that make the neighborhood one of the most active in the field of social participation [65]. All these changes affect the cultural heritage and landscape regeneration order and bring out their connoting vulnerabilities. The adoption of a holistic perspective guides the analysis and 
study of perturbative pressures acting on the cultural heritage and landscape. The systemic structure of perturbative actions impacts on the configuration of the individual component systems, on the specific dynamics of evolution, on the relationships between these and the system to which they belong, on the changes of the cultural heritage and landscape [66].

The case study of Ercolano, municipality of the Vesuvian area of the Naples Metropolitan City, in the south of Italy, falling within the buffer zone identified by UNESCO as part of the World Heritage Site, which also includes the archaeological areas of Pompeii and Torre Annunziata. The municipalities of the Vesuvian area represent an ambivalent reality: on the one hand, they are landscapes of great beauty, a social capital with high potential, and an archaeological site of inestimable value (founded in Roman times and destroyed by the eruption of Vesuvius in 79 A.D). Following the first excavation campaign in 1709, the city became one of the most popular destinations on the European Grand Tour and site, nearby Portici, where the royal family's and its court residence, were identified for heritage value as the so-called "Golden Mile". The main characteristics of Ercolano cultural heritage and landscape are the quality of natural resources compromised by a strongly stratified and heterogeneous urban fabric; conditions of physical, economic and social degradation can be traced back to phenomena of an environmental nature. These pressures are linked to social and economic dynamics and the ways in which the cultural heritage and landscape are enjoyed.

Both the cases offer the opportunity of experimenting and testing the human-centred and circular regeneration strategies in an urban context characterized by concomitant environmental, social, economic and cultural waste conditions. This aspect allows not only to operationalize the human-centred approach toward a circular city model, but also to define a methodological approach that is replicable also in other places characterized by vulnerabilities and waste conditions.

The action of comparing the two practices derives from the need to systematize an American best practice with a European one. From the first practice, it is possible to concretely deduce the systematization of the consolidated participatory principles of which the American school is the founder and pioneer. From the second practice it is possible to have feedback on the application of the latest European directives on the subject of inclusivity attentive to the construction of communities of built heritage with shared identity. The integration between consolidated American principles and the acknowledgment of European avant-garde allows to support the elaboration of a comprehensive methodological process adaptable to other contexts.

Both experiments take place in a fragmented, residual, abandoned and rejected cultural heritage and landscape which, undergoing the negative effects of growth dynamics, lose their productive and social potential over time. In both cases the cultural heritage and landscape assumes a condition of waste due to the loss of any form of connection with the urban context they belong to, determining a consequent fragmented society, based on individualistic values and on "suspended, neutralized and inverted relational modalities» [67].

The economic, social, cultural and environmental vulnerabilities shared by both case studies correspond to an equal link between communities, places and economies [32]. It has a decisive impact on cultural heritage and landscape regeneration dynamics that can be activated between processes, people, resources and places $[68,69]$. The regeneration strategies that involved both case studies move towards participatory approaches based on the human-centred vision. They experience an integrated vision, based on the identity components which constitute the "intrinsic value" of their cultural heritage and landscape and which represent the permanence in the transition processes [56].

\section{Results}

The adoption of a holistic perspective guides the knowledge and analysis of waste/ vulnerability factors of examined cultural heritage and landscape. The cultural instance underlying this approach is the declination of the concept of place according to an inte- 
grated vision $[70,71]$, in which the close links between communities, places and economies are a defining aspect of local dynamics based on the roots between processes, resources and places [68].

For this reason, it is fundamental to read the cultural heritage and landscape as "complex systems" [8,56,71] characterized by different subsystems interacting and influencing each other. From this perspective, the current vulnerability and waste conditions are interpreted as results of the perturbative pressures and actions which, in the time, have modified the evolutionary dynamics of one or more subsystems, determining impacts also in the others. On this basis, waste is not understood specifically in the physical sense but takes on a broader meaning, including cultural, social and economic aspects.

The analysis of community needs, the knowledge of the dynamics of change, the recognition of local and universal values of the landscape, the identification of resources to maintain and regenerate the built environment are the elements that substantiate the proposed circular methodology. The research experiments the integration between the systemic approach and the circular economy perspective, to analyze the whole process that, starting from the analysis of perturbative pressures and related transitional processes, interpret the consequent current vulnerability and waste conditions as potential resources to be regenerated, prefiguring regeneration strategies able to guarantee sustainable, equitable and inclusive development.

\subsection{Discretization of Examined Complex Systems in Sub-Systems}

The complexity of the interrelations and mutual influences that characterize the landscape as a complex system was analyzed through the discretization of its sub-systems (phase 1 in Figure 1) allowing the analysis of relationships, connections and interdependencies interacting in them [24,72].

Within a broad framework of perturbative pressures, the research has identified the catastrophic events and human actions as the main disruptive factors for both cases.

In Ercolano, the analysis of disruptive pressures shows that the prevailing vulnerabilities and waste conditions are to be found in [24]:

- the environmental sub-system (SEn), the progressive abandonment of valuable buildings of the 18th century, the predominance of new buildings with no constructive quality and the drastic reduction of green areas for local agricultural excellence production, have progressively led to the loss and illegibility of the historical layout, compromising their state of maintenance and the quality of life of the inhabitants;

- the social sub-system (SS), in which the high rate of poverty and unemployment determined by the Second World War has consequently favored the marginalization of the poorest people and the proliferation of criminality phenomena;

- the cultural sub-system (SC), in which the loss of local know-how related to material culture and to specific skills linked to the local production was reflected in the progressive decay of the built environment, increasing its fragility;

- the economic sub-system (SE), in which the Second World War and the lack of a subsequent unified regeneration plan has progressively limited the economy only on touristic aspects, reducing the economy linked to productive activities to a subsistence economy based on the second-hand market.

- In the Bronx, the analysis of disruptive pressures shows that the prevailing vulnerabilities and waste conditions are to be found in [72]:

- the environmental sub-system (SEn), characterized by the vulnerability of the ecosystem, the resulting environmental risks and the natural catastrophic phenomena that occur, such as flooding and hurricanes;

- the social sub-system (SS), distinguished by the vulnerability expressed by the different ethnical actors involved and by the relative risk of social exclusion often caused by the various gentrification phenomena; 
- the cultural sub-system (SC), in which the cultural involution aggravates the physical fragility of the cultural heritage and landscape, determining vulnerabilities in the built environment;

- the economic sub-system (SE), in which the stakeholders' vulnerability derived from the economic crisis and the stress of economic exclusion, determine a subsistence economy and generate an impoverishment of the market on both a small and global scale [72-74].

\subsection{Identification of Stakeholders and Decision Makers}

Following this first phase, the research has identified the active or potential stakeholders and decision makers (phase 2 in Figure 1) according to their levels of participation, interest and influence in the regeneration process [39,75]. Based on the categorization of Corporate Finance Institute [76] six categories of stakeholders were identified (Table 1). The identification is established considering the stakeholders ability to have decision-making influence and to carry out regenerative actions in a related sub-system.

Table 1. Identification of stakeholders and decision makers.

\begin{tabular}{|c|c|c|}
\hline $\begin{array}{c}\text { Stakeholders } \\
\text { Macro-Categories }\end{array}$ & Stakeholders Categories & Sub-System \\
\hline Customers & $\begin{array}{c}\text { Tourists/visitors } \\
\text { Users } \\
\text { Sports groups }\end{array}$ & $\begin{array}{c}\text { Economic } \\
\text { Environmental }\end{array}$ \\
\hline Employees & $\begin{array}{l}\text { Touristic operators } \\
\text { Archeological site's employees } \\
\text { Agricultural employees } \\
\text { Company employees } \\
\text { Industrial employees }\end{array}$ & $\begin{array}{c}\text { Economic } \\
\text { Environmental }\end{array}$ \\
\hline & Industrialists & \\
\hline Investors & $\begin{array}{c}\text { Developers } \\
\text { Corporate producers } \\
\text { Touristic agencies } \\
\text { Textile enterprises } \\
\text { Food enterprises } \\
\text { Research institutions }\end{array}$ & $\begin{array}{c}\text { Economic } \\
\text { Cultural } \\
\text { Environmental }\end{array}$ \\
\hline Suppliers and Vendors & $\begin{array}{c}\text { Suppliers and vendors for touristic } \\
\text { facilities } \\
\text { Foreign textile markets } \\
\text { Agricultural cooperatives } \\
\text { Suppliers and vendors for manufacturing } \\
\text { facilities }\end{array}$ & Economic \\
\hline Communities & $\begin{array}{l}\text { Ethnic associations } \\
\text { Neighborhood associations } \\
\text { Income associations } \\
\text { Role associations (mothers) } \\
\text { Civil society organization }\end{array}$ & $\begin{array}{c}\text { Social } \\
\text { Cultural }\end{array}$ \\
\hline Governments & $\begin{array}{l}\text { Local government } \\
\text { Heritage authorities }\end{array}$ & All \\
\hline
\end{tabular}

\subsection{An Integrated Approach for Multi-Stakeholders Engagement: Interviews and Questionnaires}

The integration of MDEPs and M-SDA helped the organization and the integration of the expressed values in a shared vision, which was used as the critical starting framework to build a participatory and shared decision-making and planning process. It consists in the adoption of a hybrid and integrated approach which, through participatory planning process, favors the awareness raising of all involved people in analyzing their problems and in searching for appropriate solutions, at the same time developing trust and focusing their priorities. Starting with the identification of perceived values and expectations of all 
local stakeholders related to the living place, it was able to identify the main critical issue on which to act through a circular regenerative strategy. The use of this approach helped to focus on the different purpose for which different survey methods were used for different categories of stakeholders, making the whole process, from the knowledge phase to the planning phase, fairer and more inclusive [55].

On the one hand, direct interviews were submitted to the decision makers in order to investigate the more influent dynamics and pressures that impact on the sub-system in which they act. On the other hand, questionnaires were submitted to local communities (single citizens, cultural associations, members of Third Sector, etc.) to investigate the unexpressed needs and the expectations and the issues considered essential for local development and for the enhancement of individual wellbeing.

In order to proceed to the discretization of the conditions of waste resulting from the impact of disturbing pressures, two working tables were organized:

- the first, to activate a dialogue with the community, through the distribution of largescale mixed questionnaires. It allowed to transpose the lifestyles of the population and to grasp their predisposition to participation and interaction with other actors;

- the second, to promote discussion with the institutions, has made it possible to identify new management models for the wastes identified. The process triggered by the working tables opens up the possibility of drawing up scenarios for rebalancing waste that take into account the interconnections between people and places, activities and territories [77].

In the first one, the community involvement was immediately operationalized through workshops, focus groups and direct consultation supported by the distribution of largescale mixed questionnaires. This active interaction with the population has shown the perception and expectations about lifestyles conditions, development opportunities, trust and willingness to collaborate and interact both with institutions and other actors. This dialogue phase allowed the researchers to propose the stakeholders' issues as key factors to support decision making and to orient it on the basis of shared and expressed visions, needs and requests [78].

In the second one, the confrontation with the institutions took place through interviews with representatives of local heritage authorities, delegates of local government bodies, members of cultural associations and organizations, exponents of Third Sector, communication and tourist agencies. The interviews were carried out both with decisionmakers already active in the territory and with those who could potentially be integrated in the elaboration of development and regeneration strategies but who are currently not yet able to influence the choices. The potential decision makers identified in this phase were integrated with those identified by expert knowledge in the previous phase, but in this case, they were derived from testing the respondents' willingness to collaborate with other actors involved in the process, thus identifying a network of potential relationships.

The experimentation of this participatory and inclusive approach aims to elaborate scenarios for rebalancing waste in a circular perspective [45] and to identify new ways of interaction between stakeholders and decision makers for the definition of regeneration strategies.

The questionnaire submitted to the local stakeholders was organized through a mix of open format questions and closed format questions, in order to deduce information about characteristics of the respondent and their perceptions, needs and expectations at the cultural (from Q3. to Q6.), social (from Q7. to Q13.), economic (from Q14. to Q19.) and environmental (from Q20. to Q24.) level.

In particular, among the different categories of closed format questions, Likert questions [79], dichotomous questions (yes or no) and multiple-choice questions were chosen.

The Likert questions were based on 5-point answers ( $1=$ not at all, $2=$ a little, $3=$ quite a lot, 4 = very much, 5 = very much) and were chosen to help the assessment on how the respondents feel towards a certain issue. Indeed, they were used to evaluate how strongly respondents agree on positive expectations about the future (Q3.1), on issues related to 
confidence in the effectiveness of projects to enhance the local cultural heritage (Q5.), on the negative influence of foreigners on the community (Q10.), on the level of perceived safety (Q11.), on trust in collaborative relations between citizens and institutions (Q14.), on active participation in the political (Q7.) and social life (Q16.), on the attention of institutions to the problems of the area $(\mathrm{Q} 15$.$) of the district/neighborhood, on their willingness to invest$ in improving the quality of life (Q17.), on the level of satisfaction with the quality of the environment (Q20.) and on the negative (Q22.) or positive (Q23.) environmental impact of their work.

Dichotomous questions (yes or no) were used to verify the presence of work based on local traditional skills (Q4.) and the consequent opportunity to find a job in another district/neighborhood (Q4.1), the opinion about the cultural value of economic activities (Q6.), the involvement by local authorities in decision-making processes (Q8.), the engagement in activities with a positive impact on community and on the enhancement of local culture (Q9.), the job stability (Q12.) and a constant income trend (Q18.), the introduction of innovative elements in entrepreneurships business model (Q19.1), and the necessity to integrate some functions in the area (Q24.).

Multiple-choice questions were used to find out the factors preventing the development of the area (Q3.), the type of degradation present in the area (Q13.), the income range (Q18.1) and the duration of work (Q19.), the degree of connection between the area and the context $(\mathrm{Q} 21$.$) and the type of connections to be improved in the area (\mathrm{Q} 21.1)$, the type of functions and activities to be enhanced (Q2.) and integrated (Q24.1),

Finally, open format questions were used for feedback about the perception of the homogeneity of recent development strategies (Q1. and Q1.1.), about the sense of identity summarized in a slogan or a keyword.

The interviews conducted with decision makers were organized on open format questions as this mode was better suited to their propensity for greater freedom of expression than the use of a preset scheme. For both questionnaires and interviews, the first set of questions (Q1.-Q2. and I1.-I2.) is indicated as a "theoretical framework" to introduce and describe the cultural background that justifies and explains the research question [80,81].

Both tables have been structured reporting questions (indicated with letter $\mathrm{Q}$ for questionnaires submitted to stakeholders and I for interviews conducted with decision-makers), answers given by respondents of Ercolano (AE) and the Bronx (AB), vulnerability and waste conditions, which are common to both cases and are described as "Negative Common Contact Points (NCCP)". Each of them was associated with a letter that corresponds to their categorization, which can be seen in Figure 2.

In both cases, the sample of respondents consists of 208 citizens, with the following characteristics:

- In Ercolano, the majority of respondents were aged between 30 and 40 years old (26\%), followed by respondents aged between 20 and 30 years old (23\%) and over $50(23 \%)$, while the respondents aged between 10 and 20 years old represent $16 \%$. Finally, the minority is represented by respondents aged between 40 and 50 years old. From a cultural point of view, only $32 \%$ of the total sample had a university education as higher education.

- In the Bronx, the majority of respondents were aged between 30 and 40 years old $(31 \%)$, followed by respondents aged between 20 and 30 years old $(25 \%)$ and over 50 $(24 \%)$, while the respondents aged between 10 and 20 years old represent $20 \%$. Finally, the minority is represented by respondents aged between 40 and 50 years old. From the cultural point of view, only $28 \%$ of the total sample had a university education as higher education.

The following Table 2 is a part of the whole Tables reported in Supplementary Materials, which shows how questions and answers from the questionnaires and interviews were organized to deduce the "Negative Common Contact Points (NCCP)". They have structured reporting questions (indicated with letter $Q$ for questionnaires submitted to stakeholders and I for interviews conducted with decision-makers), answers given by 
respondents of Ercolano (AE) and the Bronx (AB), vulnerability and waste conditions, which are common to both cases and are described as NCCP. Each of them was associated with a letter that corresponds to their categorization, as can be seen in the Supplementary Materials.

Table 2. Waste matrix based on vulnerabilities and waste conditions that determine "Negative Common Contact Points $(\mathrm{NCCP})^{\prime \prime}$. Source: elaboration of authors.

\section{CULTURAL SUB-SYSTEM}

\section{Q3. In your opinion, are there any factors preventing the development of the Area?}

\footnotetext{
AE3. $73 \%$ of respondents said that one of the main factors that prevent the local development is the widespread degradation at a social, cultural, economic and environmental level and $46 \%$ of them had a 'not at all' positive view of the future
}

AB3. $71 \%$ of respondents said that one of the main factors that prevent the local development is the widespread degradation at a social, cultural, economic and environmental level and $48 \%$ of them had a 'not at all' positive view of the future

Q4. Is your work based on local traditional skills? If not, did you have to find a job in another district/neighbourhood?

\begin{tabular}{ccc}
$\begin{array}{c}\text { AE4. 55\% state that they have skills that } \\
\text { are not based on local knowledge and } \\
\text { work in other districts/neighbourhoods }\end{array}$ & $\begin{array}{c}\text { AB1. 72\% state that they have skills that } \\
\text { are not based on local knowledge and } \\
\text { work in other districts/neighbourhoods }\end{array}$ & $\begin{array}{c}\text { NCCP_E-Import of external know-how } \\
\text { and loss of local skills }\end{array}$ \\
\hline
\end{tabular}

\subsection{Comparison Matrix: Definition of Negative and Positive Common Contact Points between Two Analyzed Case Studies}

The data obtained from the analysis of the two case studies are both quantitative (referred to the construction of the status quo) and qualitative (referred to the stakeholders' and decision makers' perceptions, needs and expectations deducted from interviews and questionnaires).

They are merged into a "waste matrix" to build a framework of common vulnerabilities and waste conditions between the two cases (phase 4 in Figure 1), determining the identification of "Negative Common Contact Points (NCCP)" on which to act.

The dialogue conducted with the privileged stakeholders and decision makers allowed the identification of expressed needs, to interpret as a starting point to orient the elaboration of a regeneration strategy based on local requirements and shared vision.

On one hand, decision makers set as a priority problem the identification and regeneration of "urban waste", represented by the large number of unused buildings and areas in a state of abandonment and decay. This situation has led to a request from institutions to develop a reuse strategy on an urban scale. The difficulties that emerged in the transition from a consultation phase to an implementation phase were related to a lack of allocation of tasks within the coordination process.

On other hand, the community and local cultural authorities identify the reduction of "social waste" as a priority problem: high unemployment and crime rates negatively affect the citizens' living conditions and the enhancement of an identity and belonging sense. The progressive estrangement between the community and the local cultural heritage has led to its progressive exclusion from local development processes. The subsequent community's awareness about the importance to participate in the decision-making process, has favored the collection of information from a large and heterogeneous sample of respondents.

In order to compare the two case studies, the matrix was drawn up by listing the Bronx and Ercolano vulnerability and waste conditions in the two side columns and highlighting those common to both in the centre, as represented in Figure 2.

Starting from the identified "Negative Common Contact Points", a second matrix was elaborated highlighting circular solutions adopted in the experiments to reduce each of the waste conditions presented in the first matrix. Indeed, the study of the perturbations of the state of the system also allows to understand the regenerative capacities of the system 
under examination, through the reading of the capacity to recreate a condition of dynamic equilibrium different from the previous one following a perturbative phenomenon.

The second matrix was, intended as a "resource matrix" in which, for each NCCP, a related "Positive Common Contact Points" was identified as regenerative solution able to transform waste in resources in a circular perspective (Figure 3).

\section{COMMON CONTACT POINTS}

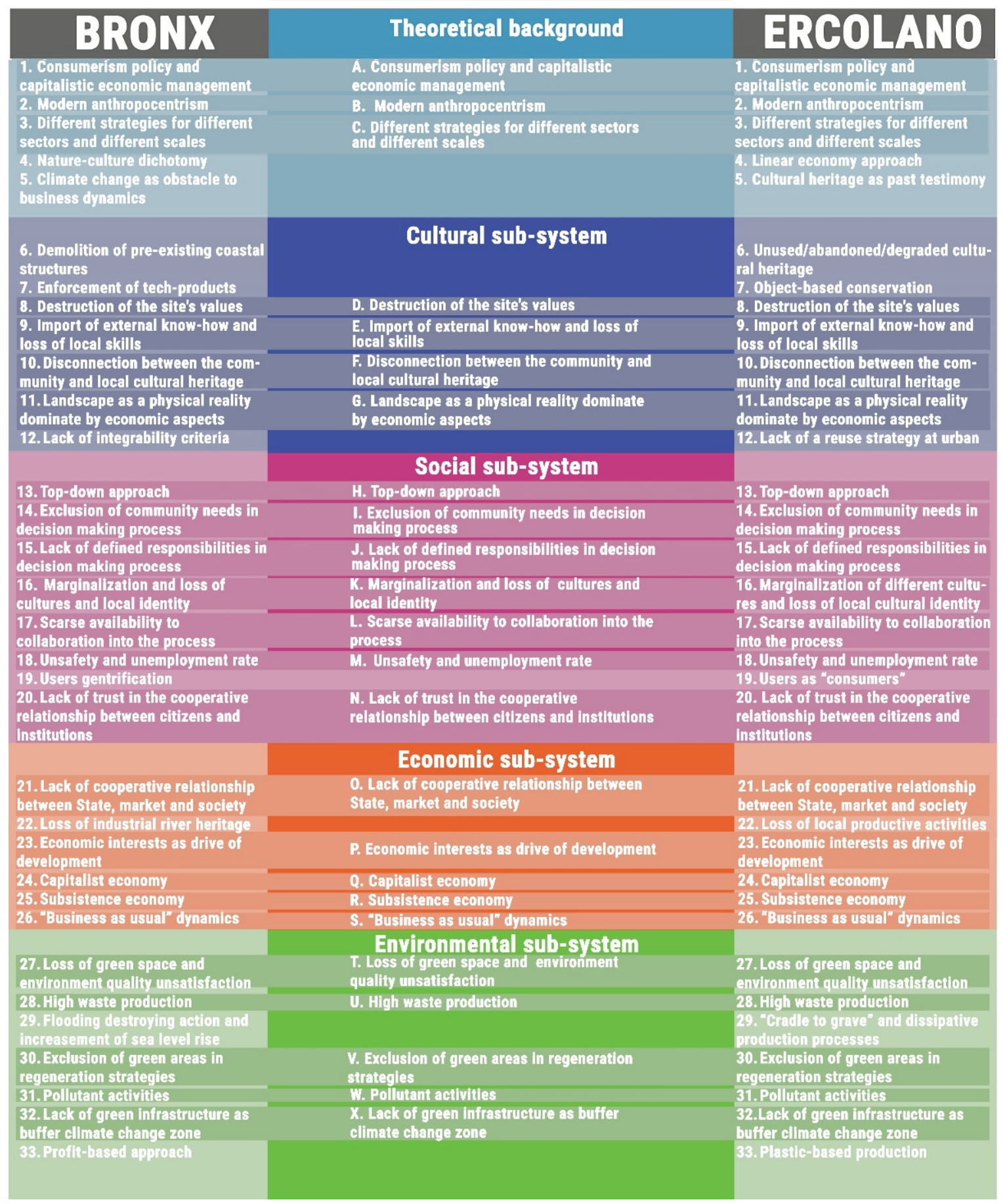

Figure 2. Waste matrix based on vulnerabilities and waste conditions that determine "Negative Common Contact Points". Source: elaboration of authors. 


\section{COMMON CONTACT POINTS}

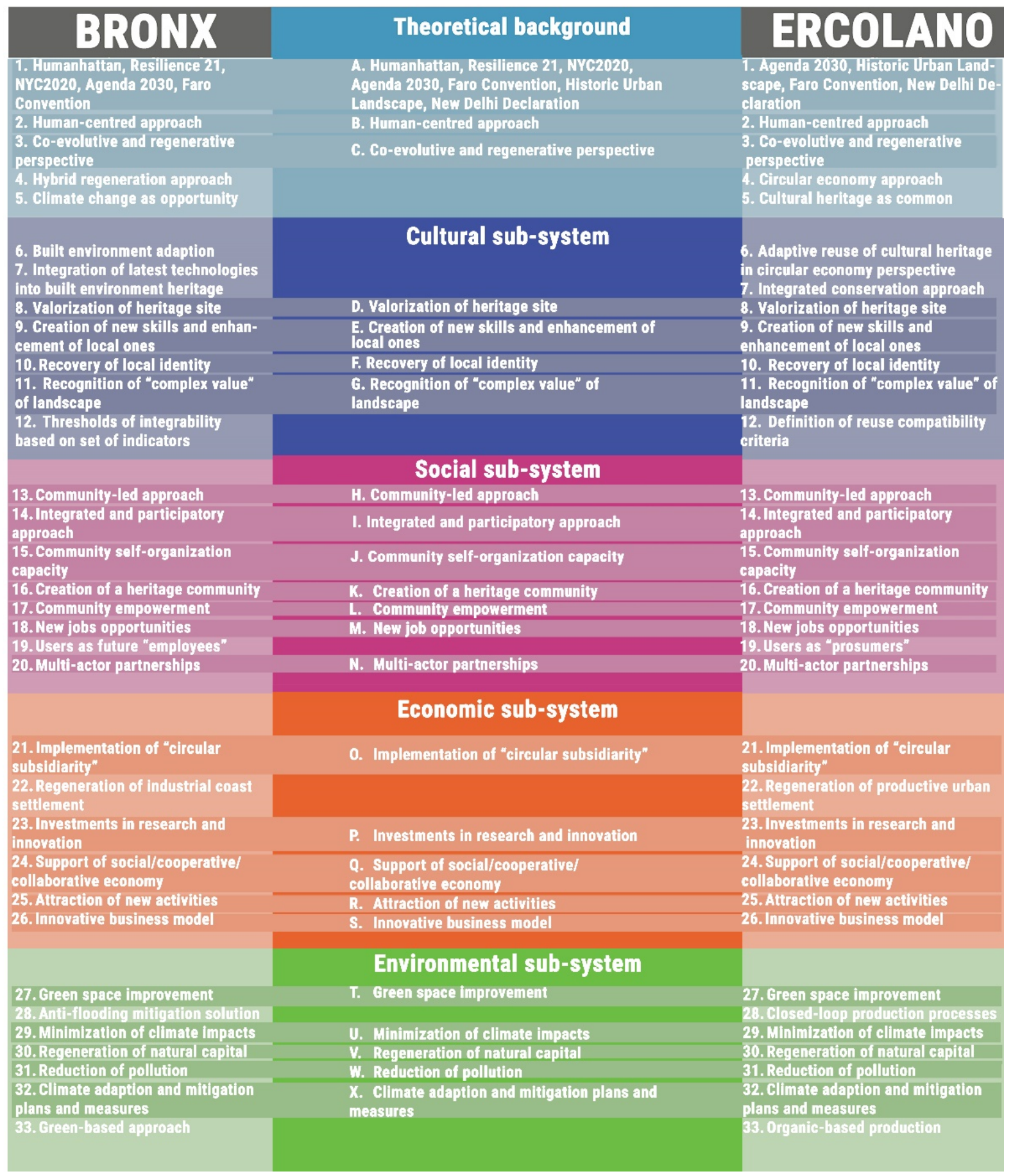

Figure 3. Resource matrix based on potential regenerative solution identified as "Positive Common Contact Points". Source: elaboration of authors.

\subsection{Human-Centred Evaluation Matrix (HCEM)}

The above analysis has highlighted the importance to define governance models adapted and aligned to the aims of global priorities and agendas [17], to achieve better measurement tools to assess the performance of cities in an integrated way [4]. Specifically included are «active participation of citizens as generators, validators and users of their own city-level data» [4]. 
Starting from these issues, the research proposes a "Human-Centred Evaluation Matrix (HCEM)". It has been built on the interconnections among the main institutional documents on the themes of sustainable development, circular economy, climate challenges and a human-centred approach.

The first column of the matrix was elaborated starting from the above-identified potentiality "Positive Common Contact Points", assuming them as "issues". The goals are represented by the SDGs as defined in the United Nations 2030 Agenda.

A first step in the elaboration of the matrix was therefore to define the correspondence between each SDG and the issues represented by the potentiality "Positive Common Contact Points" as shown in the following Table 3.

Table 3. Correspondence between Agenda 2030 SDGs and the issues represented by "Positive Common Contact Points".

\begin{tabular}{cc}
\hline Issues & Sustainability Frameworks \\
\hline Positive Common Contact Points & Agenda 2030 SDGs \\
\hline B., H., I., J., L., O., Q., S., U. & SDG 1: No Poverty \\
B., H., I., J., L., O., Q., S., U. & SDG 2: Zero Hunger \\
B., C., G., H., O., Q., T., U., V., W., X. & SDG 3: Good Health and Well-being \\
B., H., L., M., O., P., Q. & SDG 4: Quality Education \\
B., H., K., I., M., O., Q. & SDG 5: Gender Equality \\
B., H., I., L., P., S., V., W., X. & SDG 6: Clean Water and Sanitation \\
B., D., H., I., L., P., S., V., W., X. & SDG 7: Affordable and Clean Energy \\
D., E., L., M., P., R., S., U., V., X. & SDG 8: Decent Work and Economic Growth \\
B., C., D., E., F., H., I., J., L., M., O., Q., S. & SDG 9: Industry, Innovation and Infrastructure \\
B., C., D., E., G., H., J., L., M., O., P., Q., R., S., U., V., & SDG \\
B., C., D., E., F., G., H., I., J., K., L., M., O., P., Q., R., S., T., U., V., & W., X. \\
C., D., L., M., P., Q., S., U., V., W., X. & SDG 11: Sustainable Cities and Communities \\
D., G., H., I., L., P., T., U. V., W., X. & SDG 12: Responsible Consumption and Production \\
C., G., I., L., U., V., W., X. & SDG 13: Climate Action \\
C., G., I., L., T., U., V., W., X. & SDG 14: Life Below Water \\
B., C., H., I., J., L., N., O., Q. & SDG 15: Life on Land
\end{tabular}

The second step was aimed at matching and synthetizing interconnected SDGs in a more inclusive and general Goals.

The third step consisted in defining "Criteria", which represent the system attributes, i.e., the different points of view from which goals, and thus, strategies, are to be assessed [82]. For this purpose, the BES-equitable and sustainable wellbeing report [83] was chosen as the reference source. The report presented the research conducted by ISTAT (National Statistical Institute), which takes the multidimensionality of well-being as its starting point and, through the analysis of a broad set of indicators, describes the set of aspects that contribute to the quality of life of citizens. The publication is organized into 12 chapters, corresponding to the dimensions of well-being under observation: "Health", "Education and training", "Work and life-time balance", "Economic well-being", "Social relations", "Politics and institutions", "Security", "Subjective well-being", "Landscape and cultural heritage", "Environment", "Innovation, research and creativity", and "Quality of services". These dimensions were used as "Criteria" against which to categorize both the previously defined objectives and the strategies derived from the international documents analyzed. Thus, they were re-numbered in a different way, with respect to their original numbering.

The fourth step was aimed to identify current strategies that allow to orient the definition of policies and actions considering the current climate and environmental challenges [53], the guidelines for the implementation of the circular economy model [60] and for the adoption of the human-centred approach in cities $[3,4,17]$ and, finally, the main and recent document on resilient communities [61]. For this reason, the main documents recently issued at international level were chosen as reference sources: 
- the document "Circular Economy in Cities" by the Ellen MacArthur Foundation [60], for the aspects related to the implementation of the circular economy model in cities;

- the European Commission's first paper "Human-Centred City" [3], to understand how research and action can guide the transition towards more climate neutral, smart, resilient, healthy, inclusive, prosperous, safe and sustainable cities, adopting a more holistic and needs-based approach;

- the "European Green Deal" [53], for aspects related to the strategies to be adopted at the European level to ensure a fair and inclusive transition for a sustainable European economy and climate and environmental challenges. It represents an integral part of this Commission's strategy to implement the United Nations' 2030 Agenda and the Sustainable Development Goals, and the other recent European priorities [54,84]. In this perspective, the integration of the United Nations' Sustainable Development Goals in the new proposed strategies is necessary to give a central role to sustainability and the well-being of citizens in economic policy. It happens to guarantee the implementation of sustainable development goals in policy making and action at all levels.

- the "Resilience 21 building a nation of resilient communities" of Biden-Harris Administration's has launched actions to building resilient communities [61]. To lead, integrate and accelerate are drivers used to face the economic disinvestment or underinvestment, social and political disenfranchisement. They are considered in order to achieve intergenerational equity and improve social, economic and environmental determinants to strive for prosperity. As highlighted into "Resilience 21, Building a nation of resilient communities" it is important to draw on unique grit, and resources to build the nation's capacity to bounce forward from climate related shocks, into a more sustainable and equitable way of life for all communities and small businesses. Exploiting the Resilience 21 Coalition (formed at the end of 2020 by resilience experts from across the nation who are practitioners in diverse communities, working on all aspects of resilience), the document highlights 10 different actions. These recommended actions for the first 100 day of the Biden-Harris Administration can be implemented in resilient communities.

The fifth step was aimed to define "Actions" inferring them from all previous strategies and considering the operational issues expressed in the Human-Centred City document [3].

The matrix is structured to have a transversal reading that connects all the elements present on the same row: the issues derived from the case studies to achieve a specific goal (connected with the Agenda 2030 one) and to respond to certain criteria present in the BES [84]. They are implementable through the adoption of strategies proposed about the "reintegration" of the economy into ecology (green color) $[53,85,86]$ adopting a circular economy approach (light blue color) [60] towards implementing a human-centred city (orange color) $[3,4]$ for more resilient communities (yellow color). Each strategies document is colored, with arbitrary color, in order to let the reader easily matches different actions with the previous criteria and goals as described in Table 4 [61]. 
Table 4. Human-Centred Evaluation Matrix (HCEM). Source: elaboration of authors.

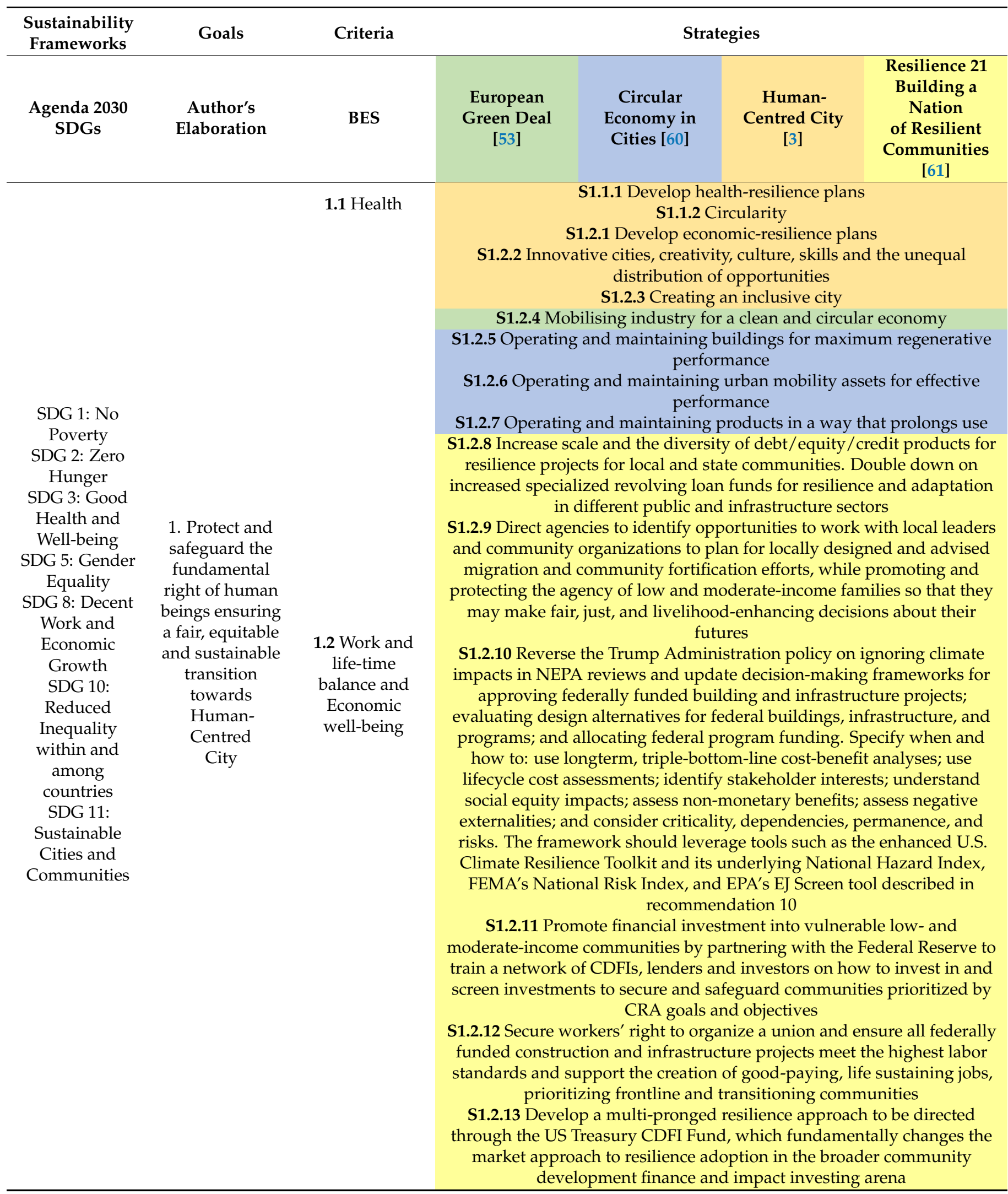


Table 4. Cont

\begin{tabular}{|c|c|c|c|c|c|c|}
\hline $\begin{array}{c}\text { Sustainability } \\
\text { Frameworks }\end{array}$ & Goals & Criteria & \multicolumn{4}{|c|}{ Strategies } \\
\hline $\begin{array}{c}\text { Agenda } 2030 \\
\text { SDGs }\end{array}$ & $\begin{array}{l}\text { Author's } \\
\text { Elaboration }\end{array}$ & BES & $\begin{array}{c}\text { European } \\
\text { Green Deal } \\
{[53]}\end{array}$ & $\begin{array}{c}\text { Circular } \\
\text { Economy in } \\
\text { Cities [60] }\end{array}$ & $\begin{array}{c}\text { Human- } \\
\text { Centred City } \\
{[3]}\end{array}$ & $\begin{array}{c}\text { Resilience } 21 \\
\text { Building a } \\
\text { Nation } \\
\text { of Resilient } \\
\text { Communities } \\
\text { [61] }\end{array}$ \\
\hline
\end{tabular}

S1.2.14 Direct the Office of Management and Budget (OMB) to coordinate on information materials needed to apply to multiple grant and subsidy programs to ease administrative burden on applicants and grantees

S1.2.15 Establish a National Green Bank-a nonprofit organization tasked with providing subsidy, grants, and loans, to support a wide range of multi-benefit projects aimed to improve environmental sustainability, disaster preparedness, climate adaptation, public health, and social equity.

Ensure that the National Green Bank does not limit its scope to energy-efficiency projects in high-income areas but prioritizes the needs of vulnerable communities and provides offerings for projects that are often overlooked

1.3 Social

S1.3.1 Make cities inclusive for all, overcoming cultural diversity,

relations

1.4 Politics and institutions building community and social bonding and avoiding fragmentation and inequalities

S1.3.2 Making products with techniques that are digitally enabled and increasingly local

S1.4.1 Define urban governance based on citizen engagement S1.4.2 Urban innovation systems, institutions and economic governance S1.4.3 Increase in investments and financing for risk protection plan and measures

S1.4.4 Increase in investments and financing to ensure access to quality essential health-care services

S1.4.5 Integration of users well-being needs in urban planning policies S1.4.6 Pursuing green finance and investment and ensuring a just transition

S1.4.7 Greening national budgets and sending the right price signals S1.4.8 Utilize resident-informed policymaking,

human/community-centred design methods to build consensus around the values and priorities that will guide federal involvement and investment in addressing climate and social justice

S1.4.9 Establish minimum resilience design standards for federally supported buildings and infrastructure to incorporate resilience to flood, wildfire, and extreme winds. Without such requirements, the resilience of federal investments in communities will rely on local requirements, which can vary widely. Minimum design, construction, and operation requirements will increase health and safety for people, assure taxpayer

dollars are used cost effectively and reduce the need for federal reinvestment post-disaster

S1.4.10 Fully implement HUD's stalled policies requiring the consideration of resilience, sustainability, social and climate justice, and fair housing in the CDBG Consolidated Planning processes S1.4.11 Establish an Office of "P4" Public Private People Partnerships to promote and enhance opportunities for private investment in projects to advance carbon mitigation, community resilience, and sustainability, including opportunities to blend public funds and private capital 
Table 4. Cont

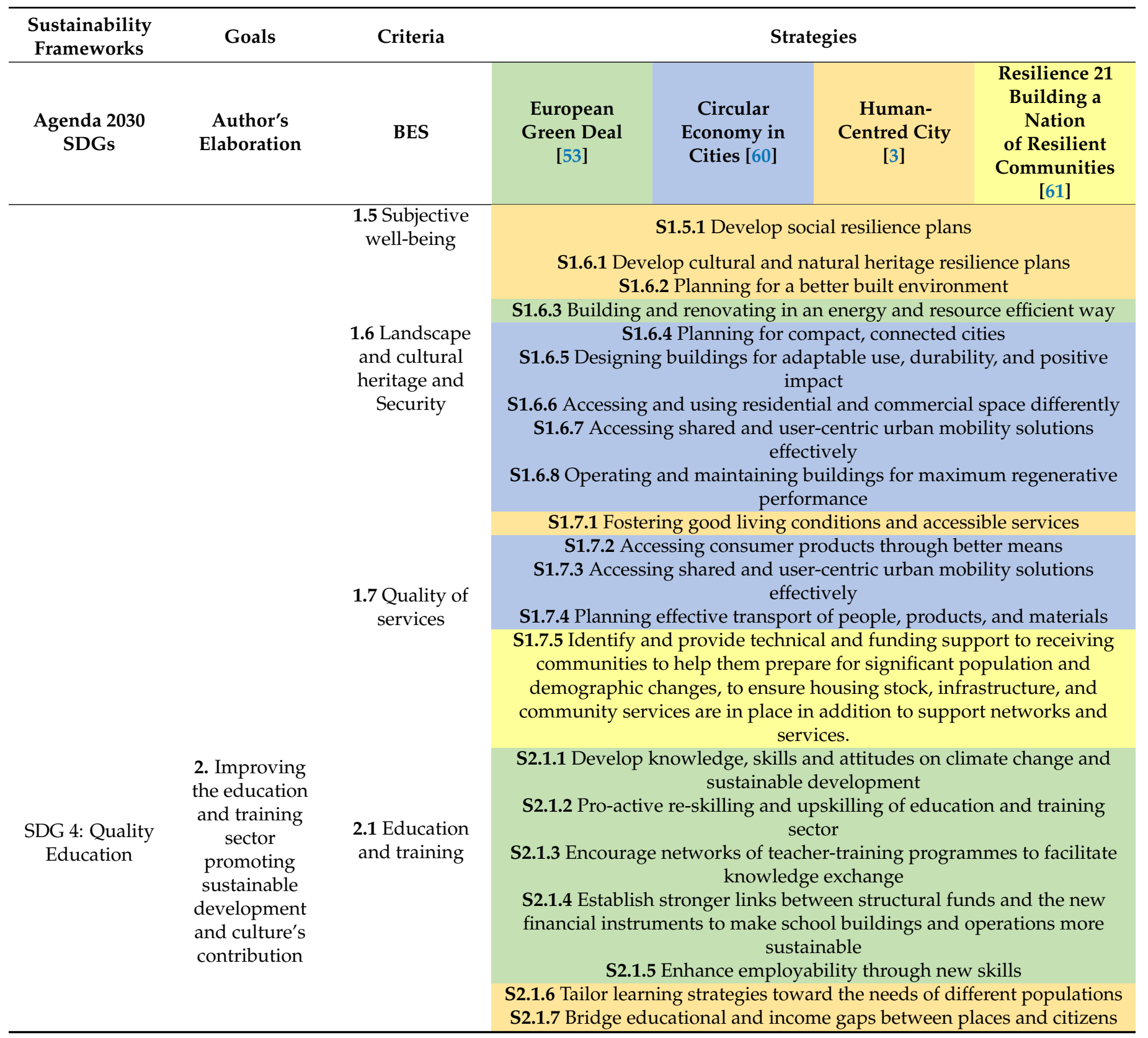


Table 4. Cont

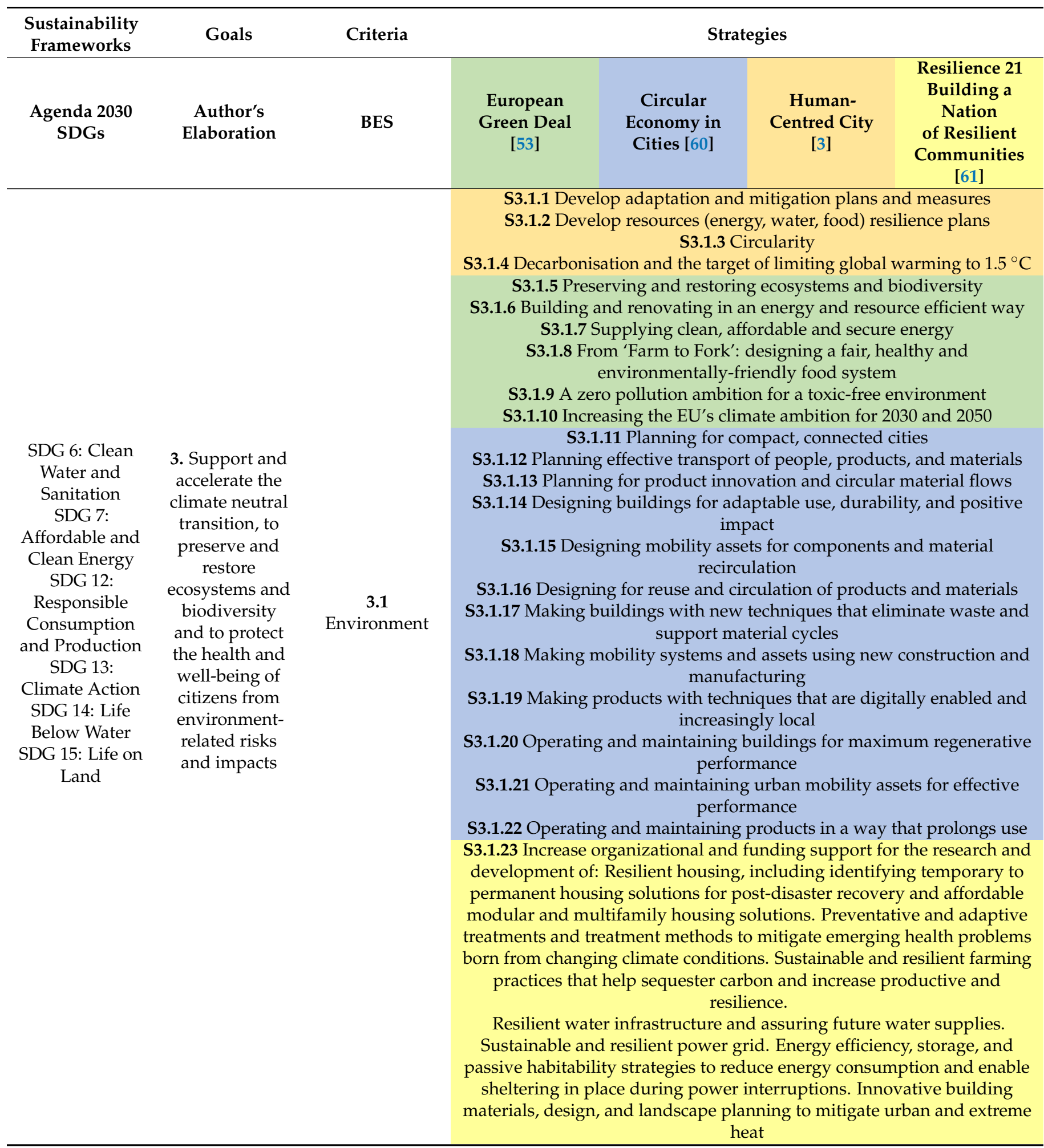


Table 4. Cont

\begin{tabular}{|c|c|c|c|c|c|c|}
\hline $\begin{array}{l}\text { Sustainability } \\
\text { Frameworks }\end{array}$ & Goals & Criteria & \multicolumn{4}{|c|}{ Strategies } \\
\hline $\begin{array}{c}\text { Agenda } 2030 \\
\text { SDGs }\end{array}$ & $\begin{array}{l}\text { Author's } \\
\text { Elaboration }\end{array}$ & BES & $\begin{array}{c}\text { European } \\
\text { Green Deal } \\
{[53]}\end{array}$ & $\begin{array}{c}\text { Circular } \\
\text { Economy in } \\
\text { Cities }[60]\end{array}$ & $\begin{array}{c}\text { Human- } \\
\text { Centred City } \\
{[3]}\end{array}$ & $\begin{array}{c}\text { Resilience } 21 \\
\text { Building a } \\
\text { Nation } \\
\text { of Resilient } \\
\text { Communities } \\
\text { [61] }\end{array}$ \\
\hline & & & 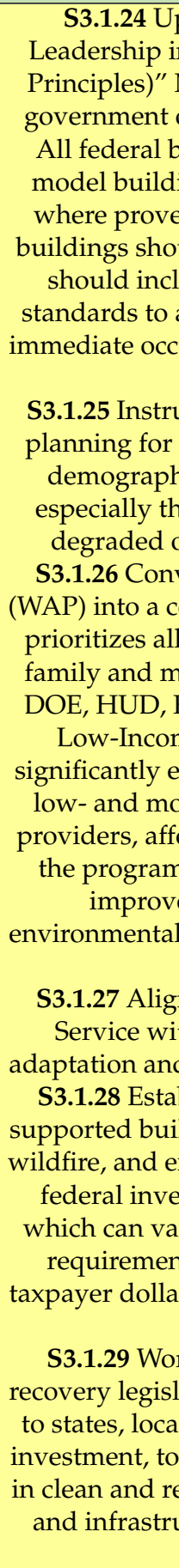 & 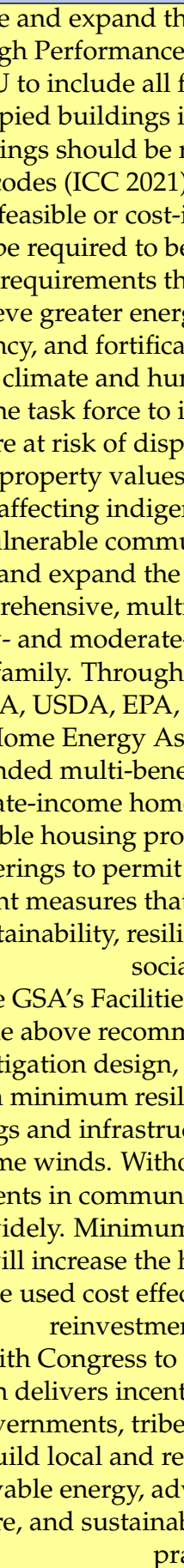 & 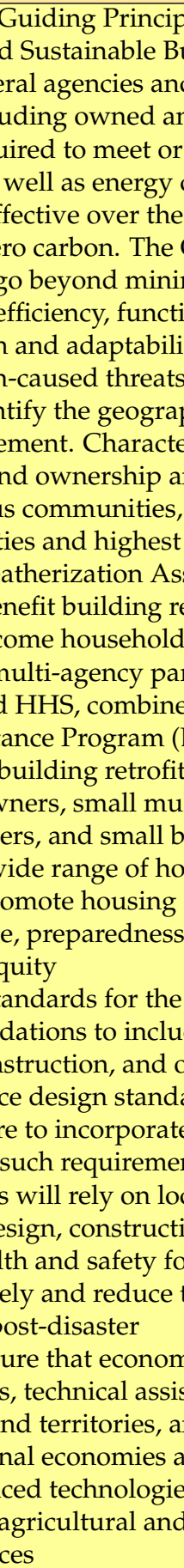 & $\begin{array}{l}\text { s for Federal } \\
\text { dings (Guiding } \\
\text { over all federal } \\
\text { leased facilities. } \\
\text { ceed the latest } \\
\text { des, and except } \\
\text { ecycle, all new } \\
\text { liding Principles } \\
\text { am (ICC 2021) } \\
\text { al recovery and } \\
\text { based on specific } \\
\text { ic areas that are } \\
\text { ze the impacted } \\
\text { other factors, } \\
\text { vironmentally } \\
\text { reat locations } \\
\text { tance Program } \\
\text { ofit program that } \\
\text { ncluding single } \\
\text { ership between } \\
\text { le WAP and the } \\
\text { HEAP) into a } \\
\text { rogram aimed at } \\
\text { family housing } \\
\text { inesses. Expand } \\
\text { e and building } \\
\text { ordability, } \\
\text { ublic health, and } \\
\text { attracts private } \\
\text { und investments } \\
\text { resilient housing } \\
\text { atural resource } \\
\text { multihazard } \\
\text { stimution standards } \\
\text { as for federally } \\
\text { esilience to flood, } \\
\text {, the resilience of } \\
\text { requirements, } \\
\text {, and operation } \\
\text { seople, assure } \\
\text { need for federal } \\
\end{array}$ \\
\hline
\end{tabular}


Table 4. Cont

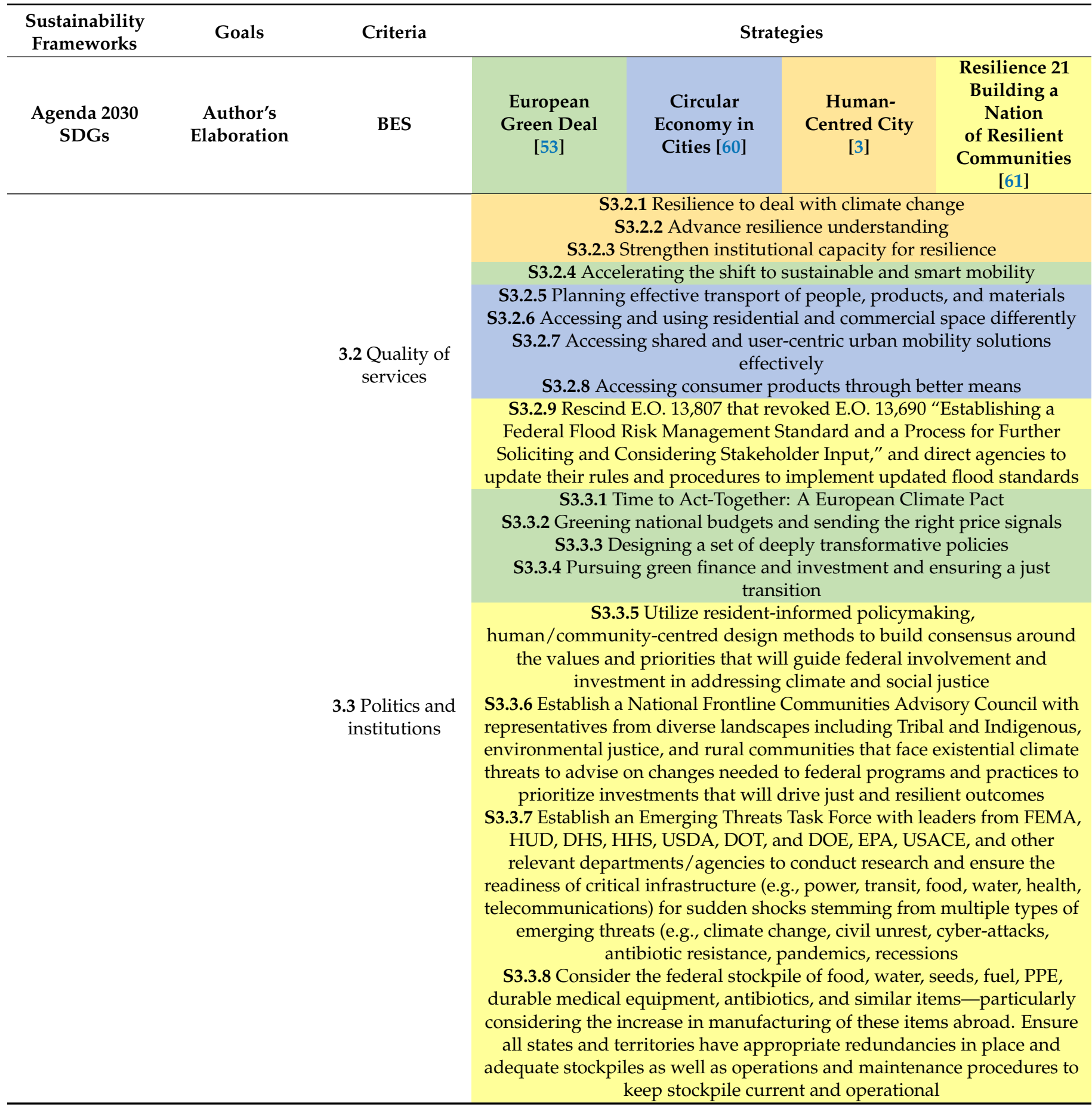


Table 4. Cont

\begin{tabular}{|c|c|c|c|c|c|c|}
\hline $\begin{array}{l}\text { Sustainability } \\
\text { Frameworks }\end{array}$ & Goals & Criteria & \multicolumn{4}{|c|}{ Strategies } \\
\hline $\begin{array}{c}\text { Agenda } 2030 \\
\text { SDGs }\end{array}$ & $\begin{array}{l}\text { Author's } \\
\text { Elaboration }\end{array}$ & BES & $\begin{array}{c}\text { European } \\
\text { Green Deal } \\
\text { [53] }\end{array}$ & $\begin{array}{c}\text { Circular } \\
\text { Economy in } \\
\text { Cities [60] }\end{array}$ & $\begin{array}{c}\text { Human- } \\
\text { Centred City } \\
{[3]}\end{array}$ & $\begin{array}{c}\text { Resilience } 21 \\
\text { Building a } \\
\text { Nation } \\
\text { of Resilient } \\
\text { Communities } \\
\text { [61] }\end{array}$ \\
\hline
\end{tabular}

S3.3.9 Expand and regularly update the U.S. Climate Resilience Toolkit to include an official, investment-grade, fully comprehensive, forward-looking set of GIS dashboards and tabular datasets that provide national- to site-level detail on a full range of natural hazards and the impacted demographics and physical assets. Integrate NOAA's Climate Explorer maps, Drought.gov (accessed on 12 May 2021), FEMA's National Risk Index, EPA's EJ Screen tool, and DOE's Renewable Energy Maps.

Enable users to add layers and conduct analyses related to their jurisdictions, constituencies, and properties as well as incorporate data for use in other tools freely without need for legal approval. Federal agencies, local governments, non profits, corporations, academics, and consumers can then use these tools to support research, policymaking, investing, and other decisions

S3.3.10 Direct all federal agencies to update their 2014 Climate Adaptation Plans and utilize the enhanced U.S. Climate Resilience Toolkit and other sources to assess the vulnerability of their constituents and assets and assess how natural hazards will affect their mission and critical paths. Direct federal agencies to adjust their programs, policies, and investments as appropriate, and with the values of long-term cost-effectiveness, environmental sustainability, and social equity in mind

S3.3.11 Expand National Earthquake Hazards Reduction Program

(NEHRP) and the National Windstorm Impact Reduction Program (NWIRP) and establish well-funded interagency programs that are tasked with enabling knowledge development and technology transfer in other natural hazard areas critical to the nation, such as fire

S3.3.12 Increase FEMA emphasis on employing adaptation, mitigation, and green infrastructure as part of all hazard mitigation funding, temporary repairs following disasters, planning and technical assistance S3.3.13 Across agencies, environmental reviews for federally funded projects should include consideration of a development's immediate impact on the natural environment, human health, and social equity; its longterm cost-benefits; and its long-term contribution and vulnerability

to the increasing natural hazards presented by climate change. All applicable federal agencies should update their environmental review policies to reflect this and, if necessary, NEPA should be updated to

support this practice. Make every effort to ensure transparency,

consistency, and efficiency in environmental reviews despite these expanded considerations. Consider rolling out changes as part of a cross-government alignment of environmental review protocols; a launch of a single, user-friendly, federal environmental review portal; a launch of a newly updated Environmental Justice Screening (EJ Screen) tool; and the expansion of the National Risk Index, which would be used when preparing and conducting the reviews

S3.3.14 Establish a price on carbon to slow climate change and accrue the funds necessary to address the damages caused by climate change S3.3.15 Appoint a Federal Chief Resilience Officer (FCRO) in the newly formed White House Office of Domestic Climate Policy that reports to the

National Climate Advisor. The FCRO should be resourced and responsible for driving resilience policy and practice across federal government operations and convening Agency Chief Resilience Officers to improve coordination and policy implementation 
Table 4. Cont

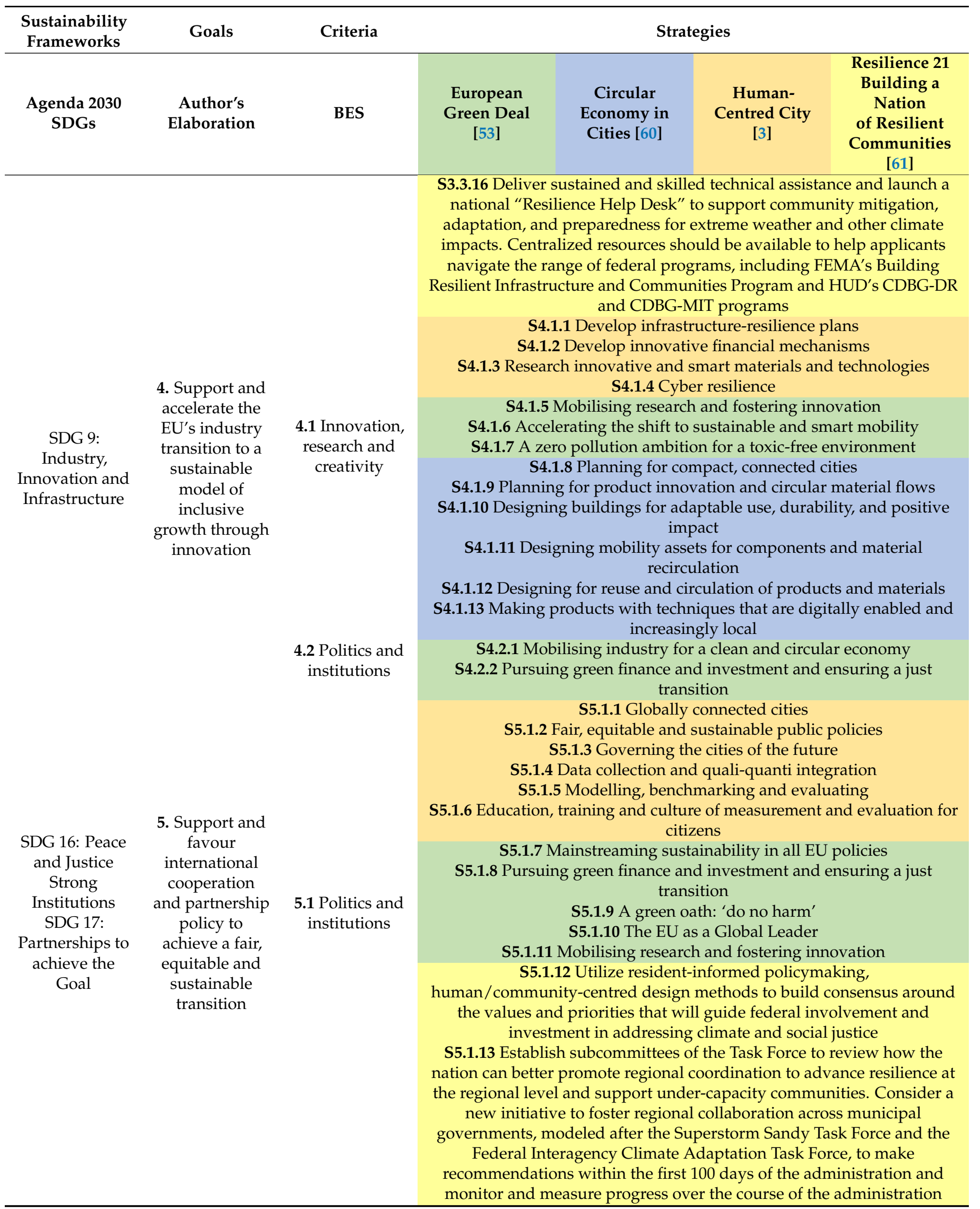


Table 4. Cont.

\begin{tabular}{|c|c|c|c|c|c|c|}
\hline $\begin{array}{l}\text { Sustainability } \\
\text { Frameworks }\end{array}$ & Goals & Criteria & \multicolumn{4}{|c|}{ Strategies } \\
\hline $\begin{array}{c}\text { Agenda } 2030 \\
\text { SDGs }\end{array}$ & $\begin{array}{l}\text { Author's } \\
\text { Elaboration }\end{array}$ & BES & $\begin{array}{c}\text { European } \\
\text { Green Deal } \\
{[53]}\end{array}$ & $\begin{array}{c}\text { Circular } \\
\text { Economy in } \\
\text { Cities [60] }\end{array}$ & $\begin{array}{c}\text { Human- } \\
\text { Centred City } \\
{[3]}\end{array}$ & $\begin{array}{c}\text { Resilience } 21 \\
\text { Building a } \\
\text { Nation } \\
\text { of Resilient } \\
\text { Communities } \\
\text { [61] }\end{array}$ \\
\hline & & & $\begin{array}{r}\text { S5.1.14 Reir } \\
\text { Native, Tribal, } \\
\text { Native and Na } \\
\text { or potential } \\
\text { S5.1.15 Ens } \\
\text { frontline and } \\
\text { siting, d } \\
\text { S5.1.16 The I } \\
\text { which will be } \\
\text { Work Plan th } \\
\text { S5.1.17 Establi } \\
\text { Strategic Resi } \\
\text { This Task F } \\
\text { (private, publi } \\
\text { econor } \\
\text { S5.1.18 D } \\
\text { adaptation prc } \\
\text { and local gov } \\
\text { S5.1.19 Appc } \\
\text { resourced to } ~ \\
\text { focused on mi } \\
\text { wit } \\
\text { S5.1.20 Establi } \\
\text { promote and e } \\
\text { advance carl } \\
\text { including } \\
\text { S5.1.21 Devel } \\
\text { develop and d } \\
\end{array}$ & $\begin{array}{l}\text { ce the right of Fr } \\
\text { d Indigenous co } \\
\text { e Hawaiian) in a } \\
\text { eats, reinforcing } \\
\text { that all potentia } \\
\text { vironmental jus } \\
\text { n, and developn } \\
\text { O will lead and } \\
\text { ponsible for dev } \\
\text { ill set achievabl } \\
\text { National Resili } \\
\text { ice Work Plan ar } \\
\text { e should include } \\
\text { vic) working to } \\
\text { activity, housing } \\
\text { lop a dashboard } \\
\text { ams to be model } \\
\text { ments can access } \\
\text { resilie } \\
\text { Agency Chief R } \\
\text { e agency level a } \\
\text { tion, adaptation } \\
\text { te FCRO as part } \\
\text { an Office of "P4" } \\
\text { ance opportuniti } \\
\text { mitigation, com } \\
\text { ortunities to ble } \\
\text { a robust, multi-s } \\
\text { oy actionable, au } \\
\text { data, models }\end{array}$ & $\begin{array}{l}\text { Prior, and Infor } \\
\text { unities (Native } \\
\text { view and consi } \\
\text { ereignty and se } \\
\text { affected stakeho } \\
\text { communities, a } \\
\text { of federally fur } \\
\text { rdinate an inter } \\
\text { ing a National } \\
\text { als and drive su } \\
\text { Task Force to i } \\
\text { nsure its deploy } \\
\text { dtitioners from } \\
\text { d community re } \\
\text { frastructure, an } \\
\text { tate resilience, } \\
\text { n the DSIRE Da } \\
\text {-to-date inform } \\
\text { efforts } \\
\text { ience Officers th } \\
\text { ns, oversee a tea } \\
\text { uity, and resilier } \\
\text { n overarching s } \\
\text { blic Private Peo } \\
\text { or private inves } \\
\text { nity resilience, a } \\
\text { ublic funds ano } \\
\text { r, multidisciplin } \\
\text { ritative, plannin } \\
\text { d information }\end{array}$ & $\begin{array}{l}\text { d Consent for } \\
\text { nerican, Alaskan } \\
\text { ration of existing } \\
\text { determination } \\
\text { ers, especially } \\
\text { involved in the } \\
\text { ed projects } \\
\text { ency task force, } \\
\text { ategic Resilience } \\
\text { essful outcomes } \\
\text { orm the National } \\
\text { ent and success. } \\
\text { ultiple sectors } \\
\text { ience in land use, } \\
\text { ducation } \\
\text { igation, and } \\
\text { base so that state } \\
\text { on on programs } \\
\text { are tasked and } \\
\text { of professionals } \\
\text {, and coordinate } \\
\text { icture } \\
\text { e Partnerships to } \\
\text { ent in projects to } \\
\text { d sustainability, } \\
\text { rivate capital } \\
\text { y partnership to } \\
\text { scale climate risk }\end{array}$ \\
\hline
\end{tabular}

The final and last step of the elaborated HCEM is the identification of 68 "HumanCentred Indicators (HCI)" (Table 5) useful in defining direct strategies (ex-ante phase), in monitoring progress (ongoing phase) and evaluating effects (ex-post phase) of the human-centred and circular city strategy implementation.

For each indicator identified, a source was attributed, which represents the reference document from which the content of the indicators is inspired. In this way, the matrix is presented both as a knowledge tool, highlighting a literature review of existing indicators on the subject, and as a proposal that brings together the major research issues to which there is an urgent need to respond.

Table 5. Human-Centred Indicators (HCI). Source: elaboration of authors.

\begin{tabular}{cccc}
\hline & Indicators & Measure & Sources \\
\hline S3.3.7 & HCI 1 Adoption of climate change, civil unrest, cyber-attacks, & Qualitative (yes /no) & [4,61] \\
S4.1.4 & $\begin{array}{c}\text { antibiotic resistance, pandemics, recessions reduction strategies } \\
\text { HCI 2 Persons affected by climate change, civil unrest, } \\
\text { cyber-attacks, antibiotic resistance, pandemics, recessions disaster }\end{array}$ & $\begin{array}{c}\text { \% (n. person affected total } \\
\text { population) }\end{array}$ & [9,61] \\
\hline
\end{tabular}


Table 5. Cont.

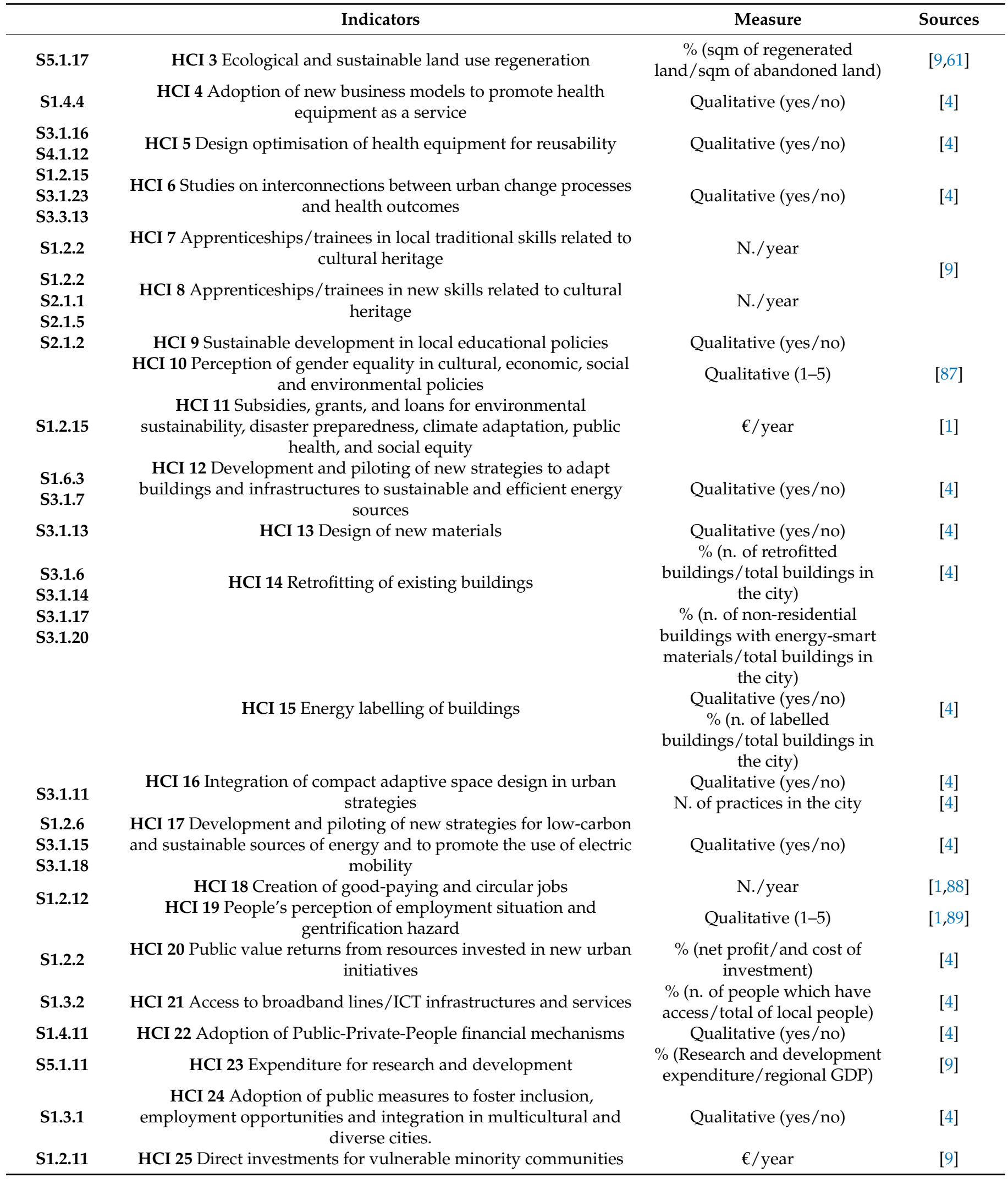


Table 5. Cont.

\begin{tabular}{|c|c|c|c|}
\hline & Indicators & Measure & Sources \\
\hline \multirow{9}{*}{ S1.3.1 } & $\begin{array}{l}\text { HCI } 26 \text { Percentage of cultural attractions that are accessible to } \\
\text { people with disabilities }\end{array}$ & $\begin{array}{l}\% \text { (accessible cultural } \\
\text { attractions/total cultural } \\
\text { attractions) }\end{array}$ & [90] \\
\hline & HCI 27 Adoption of policy-impact evaluation framework & Qualitative (yes/no) & [4] \\
\hline & $\begin{array}{l}\text { HCI } 28 \text { Social Return on Investment policies (SROI) and Social } \\
\text { Impact Evaluation (VIS) on Consolidated Planning Resilience, } \\
\text { sustainability, social and climate justice processes (CDBG). }\end{array}$ & $\begin{array}{l}\text { Index (project economic } \\
\text { outcome/ project economic } \\
\text { input) }\end{array}$ & {$[1,91]$} \\
\hline & $\begin{array}{c}\text { HCI } 29 \text { Organization of virtual and physical inter-cultural } \\
\text { initiatives }\end{array}$ & $\begin{array}{l}\text { Qualitative (yes/no) } \\
\text { N./year }\end{array}$ & {$[4]$} \\
\hline & HCI 30 Creation of multicultural spaces & $\begin{array}{c}\text { Qualitative (yes/no) } \\
\% \text { (n. of multicultural } \\
\text { spaces/total population) }\end{array}$ & [4] \\
\hline & HCI 31 Use of digital tools to create community life & Qualitative (yes/no) & [4] \\
\hline & $\begin{array}{l}\text { HCI } 32 \text { Building Participatory and inclusive Communities } \\
\text { empowerment Program }\end{array}$ & Qualitative (yes/no) & {$[1,92]$} \\
\hline & HCI 33 Foreigners participating in local community activities & $\begin{array}{l}\% \text { (n. of foreigners } \\
\text { participating/total } \\
\text { participants) }\end{array}$ & \\
\hline & $\begin{array}{l}\text { HCI } 34 \text { Perceptions of different ethnic communities in local } \\
\text { communities }\end{array}$ & Qualitative (1-5) & {$[4]$} \\
\hline \multirow{2}{*}{$\begin{array}{l}\text { S3.2.9 } \\
\text { S3.3.9 }\end{array}$} & $\begin{array}{l}\text { HCI } 35 \text { Elaboration of risk charts of sustainable heritage } \\
\text { regeneration process and natural resource practices }\end{array}$ & Qualitative (yes/no) & {$[1,9]$} \\
\hline & $\begin{array}{l}\text { HCI } 36 \text { Adoption and implementation of local disaster risk } \\
\text { reduction strategies (i.e., National Risk Index, ecc.) }\end{array}$ & Qualitative (yes/no) & [4] \\
\hline S1.6.5 & HCI 37 Adaptive reuse of cultural assets & $\begin{array}{l}\% \text { (Adaptively reused cultural } \\
\text { assets/abandoned cultural } \\
\text { assets) }\end{array}$ & [93] \\
\hline S1.7.5 & $\begin{array}{l}\text { HCI } 38 \text { Implement new funding models for sustainable urban } \\
\text { services, development and innovation policies and affordable } \\
\text { housing with special reference to public-private partnerships, } \\
\text { crowdfunding, new finance technologies, alternative models of } \\
\text { ownership (including for housing) and the use of green bonds }\end{array}$ & Qualitative (yes/no) & [4] \\
\hline S1.3.1 & HCI 39 Identification of cultural assets as "urban commons" & $\begin{array}{l}\text { \% (Number of cultural assets } \\
\text { identified as "urban } \\
\text { commons" / total of cultural } \\
\text { assets) }\end{array}$ & {$[94,95]$} \\
\hline S3.1.29 & $\begin{array}{c}\text { HCI } 40 \text { Annual expenditure on conservation, preservation and } \\
\text { reuse of cultural heritage }\end{array}$ & $\begin{array}{l}\% \text { (annual expenditure on } \\
\text { conservation, preservation } \\
\text { and reuse/total annual } \\
\text { expenditure) }\end{array}$ & [89] \\
\hline S1.3.1 & HCI 41 Discrimination actions rate & $\begin{array}{l}\% \text { (number of offenses / total } \\
\text { population) }\end{array}$ & {$[1,9]$} \\
\hline & HCI 42 Safety, security and safeguard communities prioritized rate & Qualitative (1-5) & [89] \\
\hline S1.7.5 & HCI 43 Facilities Standards for the Public Satisfaction Service & Qualitative (1-5) & {$[1,96]$} \\
\hline S3.3.12 & $\begin{array}{l}\text { HCI } 44 \text { Investment in green infrastructure climate mitigation } \\
\text { funding }\end{array}$ & $€ /$ year & [1] \\
\hline S1.3.1 & $\begin{array}{l}\text { HCI } 45 \text { Direct participation of civil society in urban planning and } \\
\text { management }\end{array}$ & $\begin{array}{c}\text { Qualitative (yes/no) } \\
\text { \% (member of civil society } \\
\text { involved/total people } \\
\text { involved) } \\
\% \text { (n. of agreement for } \\
\text { collaboration among local } \\
\text { stakeholders/total } \\
\text { population) }\end{array}$ & {$[95]$} \\
\hline
\end{tabular}


Table 5. Cont.

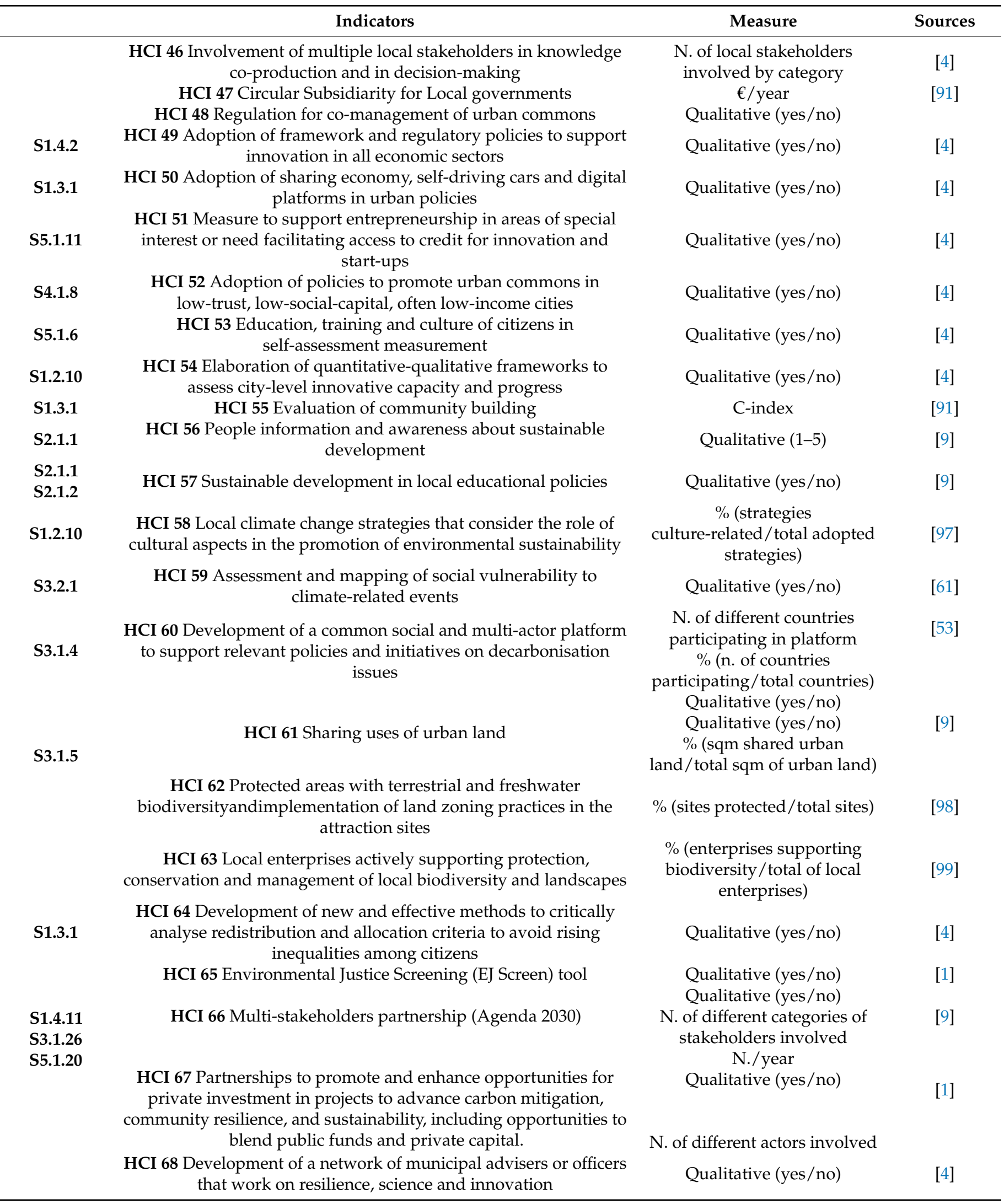




\section{New Opportunities for Circular and Human-Centred Regeneration Strategies}

The proposal to analyze regeneration strategies in the circular economy perspective allows considering degraded and abandoned spaces no longer as urban waste but as an opportunity for experimentation and potential for the cultural heritage and landscaping development.

The experimentation of the human-centred approach represents an attempt to oppose the processes of gentrification by creating a project for the community co-designed by themselves. The case studies highlight how the human-centred approach applied to codesign influences the decisions of the transformation processes of cultural heritage. The needs of the community represent in the methodological process the main factor in the realization of creative processes aimed at transforming the planning system. The citizens, in the role of "city makers" and "innovation actors" [3], can really operationalize a transition toward a human-centred and circular city $[3,4,6,7,17,19,20,31,60,100]$.

The adoption of a multi-stakeholders approach [63] in both case studies has converged in a proposal in which the satisfaction of needs expressed by communities was integrated with the requirements set by decision makers. It was done in order to define an inclusive methodology in which all stakeholders contribute to the co-creation and co-regeneration of values in multiple dimensions [31], enhancing human well-being, economic productivity and environment preservation [95].

Both proposals have configured a circular and human-centred methodology that is adaptable and replicable in other vulnerable contexts. It represents a model to support decision making towards the definition and implementation of circular and human-centred regeneration strategies.

In the same way, the similarity between the two cases emerges regarding the relation between people and place which, thanks to the experiments, has favored the improvement of community building [101]. It enhances the process of identification between the community and the place, thus reinforcing and recovering local identity, and contributing to the creation of an 'heritage community' [102]. By raising awareness and involving local communities in cultural processes, it is possible to recover and rebuild local identity [24]. It increases the sense of belonging and the construction of a community identity able to face the economic pressures regarding the regeneration policies of vulnerable cultural heritage and landscape.

The experiments reveal the need to place the community as an actor within the decision-making processes so that administrative regulations and the economic interests of developers do not overwhelm the needs of users and/or contrast their values.

The ability to translate conflictual opposites into development opportunities [103] constitutes an indispensable approach for guiding regeneration strategies aimed at creating new dynamic balances between protection and development strategies [68]. It pursues the interests of individual citizens together with the public ones, considering also the needs of future generations [104].

The Historic Urban Landscape (HUL) approach (UNESCO, 2011), as a systemic approach that is unifying/holistic, implies a continuous confrontation with the changing context, with an unstable balance that must be continuously rebuilt through an innovative management effort, taking into account the high density of interdependencies between the economic, social and ecological subsystems. The analysis and management of these interdependencies requires, first of all, the recognition of the multiple dimensions in which the value of cultural heritage is expressed, which includes in itself values of use and values independent of use (i.e., instrumental values) but also intrinsic values that, in totality, represent the overall systemic value of a cultural heritage and landscape [38].

In this perspective the landscape can be considered as a "lens" that allows to focus on the human dimension, assuming a human-centered perspective [105].

In fact, the landscape exists since a person attributes value to it based on the perception that he elaborates through his senses, determining his choices. For this reason, the landscape is the result of choices made over time by the communities that have experienced 
it and reflects both the way in which they have related to the environment and the way in which the members of the same community have related to each other. It is therefore a reflection of the culture of a society, as a human product.

The need to develop a framework for monitoring and evaluation comes from the awareness that the landscape is a living resource, conditioned in its evolution and change by the needs, interests, people expectations and, of course, by external pressures due to changes in ecosystem balances.

The adoption of a human-centred perspective in the definition of an evaluation framework introduces a relational dimension in the choices, no longer attributable only to the maximization of individual utility. This ethical and value component of the decisionmaking process is what substantiates the creation of a "responsible community". It is based on the discussion of common and shared values and not only on simple processes of deliberative democracy. In this new 'relational ethics', proposed by the German sociologist [106], individuals and communities become necessary and constitutive of each other, in a relationship of mutual support and tension. The construction of civic sense and social capital becomes the premise and objective of any prospect of development. The premise of the so-called "humanistic economy" [20], pursued in the management of cultural heritage, is based on the "intrinsic values" of exceptional interest that transcend the local reality in order to be preserved for future generations. According to this new perspective, the valuation process must be characterized by an extended rationality and can no longer be represented only in economic terms, but must also include ecological and social estimates. It reflects the complex value of cultural heritage and landscape, from both the point of view of individual "consumers" and "citizens", as members of a community founded on shared values.

The human-centred approach makes it possible to guide the transformation processes of vulnerable cultural heritage and landscape towards values capable of producing circular governance models. Participation and co-design represent the opening of complex administrative and financial processes to the members of the resident company, giving them the right to express their needs. The activation of an inclusive dialogue with the communities on regenerative transformations allows them to valorize their skills, putting them at the centre of local development and regeneration dynamics. The inclusiveness of decision-making processes increases the sharing of governance processes by determining the responsible involvement of the various actors (communities, public administrations and private investors). It influences the participation in shared actions of high physical and managerial transformative quality. The research highlights the great potential of creating successful partnerships through the collaboration between different actors, stakeholders and decision makers, to transform vulnerability in resources to be reinserted in the circular process of territorial regeneration.

The inclusiveness that characterizes the human-centred approach defines the entry of requirements necessary to satisfy the indicated needs whose response, in terms of a shared solution, returns as an integrated feedback loop. If read in a circular key, the human-centred approach offers the possibility of mitigating territorial imbalances in the various dimensions (social, economic, cultural and environmental) through practices that are attentive to the requirements of contemporaneity. These needs, carried out by integrated adaptive reuse operations, pass on the cultural heritage to future generations.

\section{Conclusions}

The research identifies in the human-centred approach the engine to develop partnerships at different levels between the actors. It has also a driver for reacting to critical issues such as strengthening social cohesion and increasing the capacity for innovation. The actions activated on vulnerable cultural heritage aim to strengthen the construction of a community aware of the "resource" value of its own heritage. The attribution of one's identity to a physical space generates a sense of belonging to a site. It exploits its vulnerabilities by associating the lack of needs of stakeholders with the opportunity to allow 
them to actively participate in the process dynamics. In fact, the local population is called to respond to consultation tables and to influence planning and administrative decisions, as they themselves will have consequences on the places they live in. This participation generates interest in participation, allows the construction of a dialogue between actors of different levels and fields of knowledge. It induces in the population the predisposition to take responsibility and to take care of the site in which they live with actions of protection and regeneration consistent with their needs. Within a circular perspective, the relationship between stakeholders and decision makers for the regeneration of the site is based on a relationship of mutual and reiterative enhancement. It triggers a circular flow of needs, requirements and performances to be satisfied with at the end of the regeneration process.

The HCI assessment framework allows guiding vulnerable cultural heritage and landscape in urban transition and regeneration practices towards Circular City models in which inclusive and participatory approaches transform waste into resources. The novelty of methodology consists in a double level of innovation. The first is a process innovation in that local stakeholders are considered in all phases of the experimentation and their needs are considered simultaneously as input and output of the circular methodology. The human-centred approach applied in the evaluation field implies a notion of value that is not exclusively economic, but includes a much broader meaning that places man and his needs at the centre, submitting to their satisfaction the definition of any value to improve the living conditions [107].

The indicators emerging from the research are aimed at providing guidance tools for actions. It can create circularity of processes and community participation around the transformation of the cultural heritage vulnerabilities into a virtuous self-sufficient circuit of resources. These indicators are guided by the human-centred approach based on the participation of a community aware of its own collective identity. The communities are able to associate and rediscover their values and the needs satisfaction transforming the vulnerable cultural heritage and landscape. The stressed human-centred approach within use of the indicators looks at the strategic relationships between the territory, stakeholders and decision makers. This relationship could be thought of as an engine for the enhancement of cultural heritage capable of strengthening the regenerative potential of the site. The indicators serve to trigger successful socio-economic processes by strengthening collaboration, culture and complementarity operations between all the actors of the process and the regenerated cultural heritage and landscape.

Supplementary Materials: The following are available online at https:/ / www.mdpi.com/article/10 .3390 / su13105505/s1, Table S1: Questions submitted to the sample of stakeholders from Ercolano and the Bronx for the iden-tification of the vulnerabilities and waste conditions defined as "Negative Common Contact Points (NCCP)"; Table S2: Questions submitted to the sample of decision-makers from Ercolano and the Bronx for the identification of the vulnerabilities and waste conditions defined as "Negative Common Contact Points (NCCP)".

Author Contributions: Conceptualization, M.B. and F.C.; data curation, M.B. and F.C.; European investigation, M.B.; American investigation F.C.; methodology, M.B. and F.C.; resources M.B. and F.C.; validation, M.B. and F.C.; writing-original draft, M.B. and F.C.; writing-review and editing M.B. and F.C. All authors have read and agreed to the published version of the manuscript.

Funding: This research received no external funding.

Institutional Review Board Statement: Not applicable.

Informed Consent Statement: Not applicable.

Data Availability Statement: No new data were created or analyzed in this study. Data sharing is not applicable to this article.

Conflicts of Interest: The authors declare no conflict of interest. 


\section{References}

1. Swyngedouw, E. Urbanization and environmental futures: Politicizing urban political ecologies. In The Routledge Handbook of Political Ecology; Routledge: London, UK, 2015; pp. 609-619. [CrossRef]

2. De Leo, D.; Lieto, L.; Palestino, M.F. La sottorappresentazione della sregolazione. Un problema di definizioni e di policies. In Ripensare la Questione Urbana. Regionalizzazione Dell'urbano in Italia e Scenari di Innovazione; Balducci, A., Fedeli, V., Curci, F., Eds.; Guerini e Associati Editore: Milano, Italy, 2017; pp. 229-255.

3. European Commission. The Human-Centred City: Opportunities for Citizens through Research and Innovation; European Commission: Luxembourg, 2019.

4. European Commission. The Human-Centred City: Recommendations for Research and Innovation Actions; European Commission: Luxembourg, 2020.

5. Ellen MacArthur Foundation. Growth within: A Circular Economy Vision for a Competitive Europe. 2015. Available online: https:/ / www.ellenmacarthurfoundation.org/assets/downloads/publications/EllenMacArthurFoundation_GrowthWithin_July15.pdf (accessed on 12 May 2021).

6. World Economic Forum. Circular Economy in Cities: Evolving the Model for a Sustainable Urban Future. 2018. Available online: http:/ / www3.weforum.org/docs/White_paper_Circular_Economy_in_Cities_report_2018.pdf (accessed on 25 March 2021).

7. Marin, J.; De Meulder, B. Interpreting Circularity. Circular City Representations Concealing Transition Drivers. Sustainability 2018, 10, 1310. [CrossRef]

8. Fusco Girard, L.; De Rosa, F.; Nocca, F. Verso il Piano Strategico di una città storica: Viterbo. BDC Boll. Del Cent. Calza Bini 2014, 14, 11-37.

9. United Nations. Transforming Our World: The 2030 Agenda for Sustainable Development; 2015. Available online: https: //www.un.org/ga/search/view_doc.asp?symbol=A/RES/70/1\&Lang=E (accessed on 12 May 2021).

10. European Commission. LEIPZIG CHARTER on Sustainable European Cities. 2007. Available online: http://www.eu2007.de/en/ News/download_docs/Mai/0524-AN/075DokumentLeipzigCharta.pdf (accessed on 12 May 2021).

11. Muminović, E.; Radosavljević, U.; Beganović, D. Strategic planning and management model for the regeneration of historic urban landscapes: The case of historic center of Novi Pazar in Serbia. Sustainability 2020, 12, 1323. [CrossRef]

12. Ros-Tonen, M.A.F.; Reed, J.; Sunderland, T. From Synergy to Complexity: The Trend Toward Integrated Value Chain and Landscape Governance. Environ. Manag. 2018, 62. [CrossRef]

13. Carr, D.; Howells, A.; Chang, M.; Hirji, N.; English, A. An integrated approach to stakeholder engagement. Healthc. Q. 2009, 12. [CrossRef]

14. Eisenbeiß, K. The SDGs Go Local! Why Cities Need to Engage in Integrated Urban Development. Available online: https: / / www.urbanet.info/sdgs-integrated-urban-development/ (accessed on 12 May 2021).

15. Mellqvist, H.; Søderkvist Kristensen, L.; van den Bosch, C.K. Participatory Green Structure Planning for Linking Urban and Rural Landscapes-A Case Study from Ronneby, Sweden. NA 2016, 28, 71-96.

16. Jones, M. The European Landscape Convention and the question of public participation. Landsc. Res. 2007, 32. [CrossRef]

17. Fusco Girard, L. The Human-Centred City Development and the Circular Regeneration. In Matera, Città del Sistema Ecologico Uomo/Società/Natura il Ruolo della Cultura per la Rigenerazione del Sistema Urbano/Territoriale; Fusco Girard, L., Trillo, C., Bosone, M., Eds.; Giannini Publisher: Naples, Italy, 2019; ISBN 978-88-6906-120-2.

18. Fusco Girard, L.; Nocca, F. La rigenerazione del "Sistema Matera" nella prospettiva dell'economia circolare. In Matera, Città del Sistema Ecologico Uomo/Società/Natura il Ruolo della Cultura per la Rigenerazione del Sistema Urbano/Territoriale; Fusco Girard, L., Trillo, C., Bosone, M., Eds.; Giannini Publisher: Naples, Italy, 2019; pp. 69-100.

19. Bosone, M.; Fusco Girard, L. Nuovo Umanesimo e rigenerazione urbana: l'economia civile tra l'economia della scuola francescana e l'economia circolare per la città prospera ed inclusiva. In Matera, Città del Sistema Ecologico Uomo/Società/Natura il Ruolo della Cultura per la Rigenerazione del Sistema Urbano/Territoriale; Fusco Girard, L., Trillo, C., Bosone, M., Eds.; Giannini Publisher: Naples, Italy, 2019; pp. 101-109, ISBN 9788869061202.

20. Girard, L.F. The City and the Territory System: Towards The "New Humanism" Paradigm. Agric. Agric. Sci. Procedia 2016. [CrossRef]

21. Fusco Girard, L. Risorse Architettoniche e Culturali: Valutazioni e Strategie di Conservazione; Franco Angeli: Milano, Italy, 1987.

22. Fusco Girard, L.; Nijkamp, P. Le Valutazioni per lo Sviluppo Sostenibile della Città e del Territorio; Franco Angeli: Milan, Italy, 1997; ISBN 978-88-464-0182-3.

23. Tagliagambe, S. L'albero Flessibile. La Cultura della Progettualità; Dunod: Milano, Italy, 1998.

24. Bosone, M. Recupero e Gestione dei Beni Comuni: Processi di Riuso dei Sistemi Insediativi. Ph.D. Thesis, University of Naples Federico II, Naples, Italy, 2019.

25. Magnaghi, A. Il Progetto Locale. Verso la Coscienza di Luogo; Bollati Boringhieri: Torino, Italy, 2010.

26. Marini, S. Nuove Terre. Architetture e Paesaggi dello Scarto; Quodlibet: Macerata, Italy, 2011; ISBN 8874623747r978-8874623747.

27. Iodice, S.; De Toro, P. Waset and wasted landscapes: Focus on abandoned industrial areas. Detritus 2020, 103-120. [CrossRef]

28. Cerreta, M.; De Rosa, F.; De Toro, P.; Inglese, P.; Iodice, S. Da wastescape a risorsa: Approcci multimetodologici per la rigenerazione dei paesaggi di scarto. BDC Boll. del Cent. Calza Bini 2019, 19. [CrossRef]

29. Florida, R.; Kloosterman, R.; Franke, S.; Verhagen, E. Creativity and the City: How the Creative Economy is Changing the City; NAI Publishers: New York, NY, USA, 2006; ISBN 978-9056624613. 
30. Fusco Girard, L. Discourse of Professor Luigi Fusco Girard at the European Parliament High-Level European Parliament Conference "Cultural Heritage in Europe: Linking Past and Future". In Proceedings of the European Parliament Conference "Cultural Heritage in Europe: Linking Past and Future", Hemicycle of the European Parliament, Brussels, Belgium, 26 June 2018.

31. Fusco Girard, L.; Nocca, F. Moving towards the circular economy/city model: Which tools for operationalizing this model? Sustainability 2019, 11, 6253. [CrossRef]

32. Lazzati, G. La Città dell'uomo. Costruire, da Cristiani, la Città dell'uomo a Misura D'uomo; Ave: Roma, Italy, 1984.

33. Dossetti, G. Per la Vita della Città; Zikkaron: Marzabotto, Bologna, Italy, 2017; ISBN 9788899720322.

34. Galavotti, E. La vita di Giuseppe Dossetti a servizio della città dell'uomo. Il Tetto 2013, 296-297, 51-80.

35. La Pira, G. Le Città Sono Vive; La Scuola: Brescia, Italy, 2014; ISBN 8835016029.

36. Girardet, H. Creating Regenerative Cities; Routledge: London, UK, 2014.

37. Girardet, H. Regenerative Cities; Routledge: London, UK, 2017.

38. Fusco Girard, L. Implementing the circular economy: The role of cultural heritage as the entry point. which evaluation approaches? BDC Boll. Del Cent. Calza Bini 2019, 19, 245-277.

39. Beauregard, R.A.; Lieto, L. Planning for a Material World; Routledge: London, UK, 2016.

40. Ansell, C.; Gash, A. Collaborative governance in theory and practice. J. Public Adm. Res. Theory 2008. [CrossRef]

41. Wood, D.J.; Gray, B. Toward a Comprehensive Theory of Collaboration. J. Appl. Behav. Sci. 1991. [CrossRef]

42. Mitchell, V.; Ross, T.; May, A. Empirical investigation of the impact of using co-design methods when generating proposals for sustainable travel solutions. CoDesign 2015, 12, 205-220. [CrossRef]

43. Trischler, J.; Pervan, S.J.; Kelly, S.J. The Value of Codesign. J. Serv. Res. 2017, 21, 75-100. [CrossRef]

44. De Magalhães, C. Urban Regeneration. In International Encyclopedia of the Social \& Behavioral Sciences, 2nd ed.; Pergamon: Oxford, UK, 2015; pp. 919-925. [CrossRef]

45. Sanders, E.; Stappers, P.J. Co-creation and the new landscapes of design. CoDesign 2008, 4, 5-18. [CrossRef]

46. Pieters, M.; Jansen, S. The 7 Principles of Complete Co-creation. Available online: http://universaldesign.ie/exploreampdiscover/ the7principles (accessed on 12 May 2021).

47. Caterina, G. Innovative strategies for the recovery of historic cities. TECHNE 2016, 12, 30-37.

48. McCarthy, J. Partnership, Collaborative Planning and Urban Regeneration; Taylor \& Francis: London, UK, 2016.

49. Boeri, A.; Gaspari, J.; Gianfrate, V.; Longo, D.; Pussetti, C. The adaptive reuse of historic city centres. Bologna and Lisbon: Solutions for urban regeneration. TECHNE 2016. [CrossRef]

50. Izvercianu, M.; Şeran, S.A.; Branea, A.-M. Prosumer-oriented Value Co-creation Strategies for Tomorrow's Urban Management. Procedia Soc. Behav. Sci. 2014. [CrossRef]

51. BIG Humanhattan for Rebuild by Design. 2018. Available online: http://www.rebuildbydesign.org/news-and-events/updates/ big-u-featured-at-venice-architecture-biennale (accessed on 12 May 2021).

52. Prior, J.; Tavano Blessi, G. Social Capital, Local Communities and Culture-led Urban Regeneration Processes: The Sydney Olympic Park Experience. Cosmop. Civ. Soc. J. 2012, 3, 78-96. [CrossRef]

53. European Commission. The European Green Deal; European Commission: Brussels, Belgium, 2019.

54. European Commission. Communication from the Commission to the European Parliament, the European Council, the Council, the European Economic and Social Committee and the Committee of the Regions A New Industrial Strategy for Europe: 2020. Available online: https: / / eur-lex.europa.eu/legal-content/EN/TXT/PDF/?uri=CELEX:52020DC0102\&from=EN (accessed on 12 May 2021).

55. Beauregard, R.A. Cities in the Urban Age: A Dissent; University of Chicago Press: Chicago, IL, USA, 2018.

56. UNESCO. Recommendation on the Historic Urban Landscape. 2011. Available online: https://whc.unesco.org/uploads/ activities/documents/activity-638-98.pdf (accessed on 12 May 2021).

57. Kallis, G.; Norgaard, R.B. Coevolutionary ecological economics. Ecol. Econ. 2010. [CrossRef]

58. Commoner, B. The Closing Circle: Nature, Man and Technology; Random House Inc.: New York, NY, USA, 1972; ISBN 055312921X.

59. Hannis, M. Freedom and Environment: Autonomy, Human Flourishing and the Political Philosophy of Sustainability, 1st ed.; Routledge: London, UK, 2016; ISBN 9781138777279.

60. Ellen MacArthur Foundation. Circular Economy in Cities: Project Guide. 2019. Available online: https://www. ellenmacarthurfoundation.org/assets/downloads/CE-in-Cities-Project-Guide_Mar19.pdf (accessed on 12 May 2021).

61. Biden, J. Resilience 21. Building a Nation of Resilient Communities; USA Government: Washington, DC, USA, 2021.

62. Folke, C.; Carpenter, S.R.; Walker, B.; Scheffer, M.; Chapin, T. Rockstrom Resilience Thinking: Integrating Resilience, Adaptability and Transformability. Ecol. Soc. 2010, 15, 4-20. [CrossRef]

63. UNDP. Multi-Stakeholder Engagement Processes. Capacity Development Group, Bureau for Development Policy, UNDP: New York, NY, USA, 6 November 2006. Available online: https://www.undp.org/content/dam/aplaws/publication/ en/publications / capacity-development/drivers-of-change/accountability / multi-stakeholder-engagement-processes / Engagement-Processes-cp7.pdf (accessed on 12 May 2021).

64. Cerreta, M.; Panaro, S. From Perceived Values to Shared Values: A Multi-Stakeholder Spatial Decision Analysis (M-SSDA) for Resilient Landscapes. Sustainability 2017, 9, 1113. [CrossRef]

65. Paganin, G.; Talamo, C.; Atta, N. Knowledge management and resilience of urban and territorial systems. TECHNE 2018, 15, 124-133. [CrossRef] 
66. Diano, D. Le pressioni perturbative di Torre Annunziata. BDC Boll. Del Cent. Calza Bini 2015, 15, 39-60. [CrossRef]

67. Augè, M. Nonluoghi. Introduzione a Un'antropologia della Surmodernità; Elèuthera: Milano, Italy, 2009.

68. Pinto, M.R.; Viola, S. Identità sedimentate e nuova prosperità per il paesaggio urbano produttivo. BDC Boll. Del Cent. Calza Bini 2015, 15, 71-91. [CrossRef]

69. Onesti, A. Built environment, creativity, social art: The recovery of public space as engine of human development. Region 2017. [CrossRef]

70. Santagata, W.; Bertacchini, E.; Bravo, G.; Marrelli, M. Cultural Commons and Cultural Communities. In Proceedings of the "Sustaining Commons: Sustaining Our Future, the Thirteenth Biennial Conference of the Internatonal Associaton for the Study of the Commons", Hyderabad, India, 10-14 January 2011; pp. 10-14.

71. Fusco Girard, L. The role of cultural urban landscape towards a new urban economics: New structural assets for increasing economic productivity through hybrid processes. Hous. Policies Urban Econ. 2014, 1, 3-27.

72. Ciampa, F. Participatory design approach for the Bronx waterfront. In Proceedings of the 6th International Virtual Conference on Advanced Scientific Results, Budapest, Slovakia, 25 June 2018; Volume 6, pp. 202-206. [CrossRef]

73. Street, P. Scenario workshops: A participatory approach to sustainable urban living? Futures 1997, 29, 139-158. [CrossRef]

74. Bradley, J.; Whitmore, E. Framing participatory evaluation. Wiley Online Library 2004, 80, 10-23.

75. Project Management Institute. A Guide to the Project Management Body of Knowledge: PMBOK Guide, 5th ed.; Project Management Institute: Newtown Square, PA, USA, 1996; ISBN 9781628251845.

76. Corporate Finance Insititute Stakeholder. Available online: https://corporatefinanceinstitute.com/resources/knowledge/ finance/stakeholder/ (accessed on 7 May 2021).

77. Healey, P. Collaborative Planning in perspective. Plan. Theory 2003. [CrossRef]

78. Bagnoli, A.; Clark, A. Focus groups with young people: A partecipatory approach to research planning. J. Youth Stud. 2010, 3, 101-119. [CrossRef]

79. Joshi, A.; Kale, S.; Chandel, S.; Pal, D. Likert Scale: Explored and Explained. Br. J. Appl. Sci. Technol. 2015, 7. [CrossRef]

80. Abend, G. The meaning of "Theory". Sociol. Theory 2008, 26, 173-199. [CrossRef]

81. Swanson, R.A. Theory Building in Applied Disciplines; Berrett-Koehler Publishers: San Francisco, CA, USA, 2013.

82. Cerreta, M.; De Toro, P. Valutazioni integrate ed approcci metodologici per la sostenibilità del territorio. Aestimum 2002. [CrossRef]

83. Nissi, E.; Sarra, A. A Measure of Well-Being Across the Italian Urban Areas: An Integrated DEA-Entropy Approach. Soc. Indic. Res. 2018, 136. [CrossRef]

84. Von der Leyen, U. A Union that strives for more. My agenda for Europe: Political guidelines for the next European Commission 2019-2024. 2019. Available online: https:/ / ec.europa.eu/info/sites/default/files/political-guidelines-next-commission_en_0. pdf (accessed on 12 May 2021).

85. Fusco Girard, L. The circular economy in transforming a died heritage site into a living ecosystem, to be managed as a complex adaptive organism. Aestimum 2020. [CrossRef]

86. Zeleny, M.; Hufford, K.D. The application of autopoiesis in systems analysis: Are autopoietic systems also social systems? Int. J. Gen. Syst. 1992, 21, 145-160. [CrossRef]

87. Fisher, R.; Figueira, C. Compendium of Cultural Policies and Trends in Europe. 2011. Available online: https://www. culturalpolicies.net/ (accessed on 12 May 2021).

88. Circle Economy. Circular Jobs. Available online: https://assets.website-files.com/5d26d80e8836af2d12ed1269/604b1ce1bd5a7 ecc9e17f9ec_20210311\%20-\%20CJI\%20Brief\%201\%20-\%20297x210mm.pdf (accessed on 14 May 2021).

89. Labadi, S. Evaluating the Socio-Economic Impacts of Selected Regenerated Heritage Sites in Europe; European Cultural Foundation: Amsterdam, The Netherlands, 2011.

90. European Commission. The European Tourism Indicator System (ETIS) Toolkit 2016; European Commission: Luxembourg, 2016; ISBN 9789279552496.

91. Zamagni, S.; Venturi, P.; Rago, S. Valutare l'impatto sociale. La questione della misurazione nelle imprese sociali. Impresa Soc. 2015, 6, 77-97.

92. Mercer, C. Towards Cultural Citizenship: Tools for Cultural Policy and Development; Gidlund: Hedemora, Sweden, 2002; ISBN 9178446228.

93. Licciardi, G.; Amirtahmasebi, R. The Economics of Uniqueness. Investing in Historic City Cores and Cultural Heritage Assets for Sustainable Development; The World Bank, Ed.; The World Bank Group: Washington, DC, USA, 2012; ISBN 978-0-8213-9650-6.

94. Ranocchiari, S.; Mager, C. Bologne et Naples au prisme des biens communs: Pluralité et exemplarité de projets de gestion «commune» de l'urbainBologna and Naples through the prism of common goods: Plurality and exemplary of «common» urban management projects. Dév. Durable Territ. 2019. [CrossRef]

95. Nocca, F.; Fusco Girard, L. Towards an integrated evaluation approach for cultural urban landscape conservation/regeneration. Region 2018. [CrossRef]

96. Montalto, V.; Tacao Moura, C.; Panella, F.; Alberti, V.; Becker, W.; Saisana, M. The Cultural and Creative Cities Monitor: 2019 Edition; Publications Office of the European Union: Luxembourg, 2019; ISBN 978-92-76-08806-6. [CrossRef]

97. United Cities and Local Governments (UCLG). Culture in the Sustainable Development Goals: A Guide for Local Action; 2015. Available online: http:/ / www.agenda21culture.net/sites/default/ files/culturesdgs_web_en.pdf (accessed on 12 May 2021). 
98. United Nations. Indicators for Monitoring the Millennium Development Goals. Definitions, Rationale, Concepts and Sources; United Nations: New York, NY, USA, 2003; ISBN 92-1-161467-8.

99. European Union. European Tourism Indicator System. ETIS TOOLKIT For Sustainable Destinations Management; Publications Office of the European Union: Luxembourg, 2016; ISBN 978-92-79-55247-2. [CrossRef]

100. Fusco Girard, L. Creative Cities: The Challenge of "Humanization" In The City Development. BDC Boll. Del Cent. Calza Bini 2013, 1, 9-33. [CrossRef]

101. Rajan, R. The Third Pillar: How Markets and the State Leave the Community Behind; Penguin Pr: London, UK, 2019; ISBN 9780525558323.

102. Council of Europe. Convention on the Value of Cultural Heritage for Society (Faro Convention, 2005); Council of Europe: Strasbourg, France, 2005.

103. Nocca, F. The Role of Cultural Heritage in Sustainable Development: Multidimensional Indicators as Decision-Making Tool. Sustainability 2017, 9, 1882. [CrossRef]

104. World Commission on Environment and Development. Report of the World Commission on Environment and Development. Our Common Future; United Nations: New York, NY, USA, 2017.

105. Fusco Girard, L. Editoriale. BDC Boll. Del Cent. Calza Bini 2019, 2, 233-243. [CrossRef]

106. Cerreta, M.; De Toro, P. Integrated Spatial Assessment for a Creative Decision-making Process: A Combined Methodological Approach to Strategic Environmental Assessment. Int. J. Sustain. Dev. 2010, 13, 17-30. [CrossRef]

107. Ikegami, J. The economics of intrinsic value-A note on the value theory of J. Ruskin and A. Sen. Kyoto Univ. Econ. Rev. 1992, 62, $1-17$. 